Article

\title{
Evaluating Evaporative Cooling Assisted Solid Desiccant Dehumidification System for Agricultural Storage Application
}

\author{
Ghulam Hussain ${ }^{1}$, Muhammad Aleem ${ }^{1}\left(\mathbb{D}\right.$, Muhammad Sultan ${ }^{1, *}{ }^{\mathbb{C}}$, Uzair Sajjad ${ }^{2}$, Sobhy M. Ibrahim ${ }^{3} \mathbb{D}^{1}$,
} Redmond R. Shamshiri ${ }^{4, *}{ }^{+}$, Muhammad Farooq ${ }^{5}\left(\mathbb{D}\right.$, Muhammad Usman Khan ${ }^{6}$ and Muhammad Bilal ${ }^{1}$ (i)

1 Department of Agricultural Engineering, Faculty of Agricultural Sciences \& Technology, Bahauddin Zakariya University, Multan 60800, Pakistan; aaeamri@gmail.com (G.H.); muhammadaleem189@gmail.com (M.A.); bilalranauni@gmail.com (M.B.)

2 Department of Mechanical Engineering, National Yang Ming Chiao Tung University, Hsinchu 300, Taiwan; energyengineer01@gmail.com

3 Department of Biochemistry, College of Science, King Saud University, P.O. Box 2455, Riyadh 11451, Saudi Arabia; syakout@ksu.edu.sa

4 Department of Engineering for Crop Production, Leibniz Institute for Agricultural Engineering and Bioeconomy, 14469 Potsdam, Germany

5 Department of Mechanical Engineering (New Campus-KSK), University of Engineering and Technology, Lahore 54890, Pakistan; engr.farooq@uet.edu.pk

6 Department of Energy Systems Engineering, Faculty of Agricultural Engineering and Technology, University of Agriculture, Faisalabad 38040, Pakistan; usman.khan@uaf.edu.pk

* Correspondence: muhammadsultan@bzu.edu.pk (M.S.); rshamshiri@atb-potsdam.de (R.R.S.); Tel.: +92-333-610-8888 (M.S.)

check for updates

Citation: Hussain, G.; Aleem, M.;

Sultan, M.; Sajjad, U.; Ibrahim, S.M.; Shamshiri, R.R.; Farooq, M.; Usman Khan, M.; Bilal, M. Evaluating Evaporative Cooling Assisted Solid Desiccant Dehumidification System for Agricultural Storage Application. Sustainability 2022, 14, 1479. https:// doi.org/10.3390/su14031479

Academic Editor: Emanuele Radicetti

Received: 29 December 2021

Accepted: 24 January 2022

Published: 27 January 2022

Publisher's Note: MDPI stays neutral with regard to jurisdictional claims in published maps and institutional affiliations.

Copyright: (C) 2022 by the authors. Licensee MDPI, Basel, Switzerland. This article is an open access article distributed under the terms and conditions of the Creative Commons Attribution (CC BY) license (https:// creativecommons.org/licenses/by/ $4.0 /)$.

\begin{abstract}
The study aims to investigate Maisotsenko cycle evaporative cooling assisted solid desiccant air-conditioning (M-DAC) system for agricultural storage application. Conventional air-conditioning (AC) systems used for this application are refrigeration-based which are expensive as they consume excessive amount of primary-energy. In this regard, the study developed a lab-scale solid silica gel-based desiccant AC (DAC) system. Thermodynamic performance of the developed system was investigated using various adsorption/dehumidification and desorption/regeneration cycles. The system possesses maximum adsorption potential i.e., $4.88 \mathrm{~g} / \mathrm{kg}$-DA at higher regeneration temperature of $72.6^{\circ} \mathrm{C}$ and long cycle time i.e., $60 \mathrm{~min}: 60 \mathrm{~min}$. Moreover, the system's energy consumption performance was investigated from viewpoints of maximum latent, sensible, and total heat as well as latent heat ratio (LHR), which were found to be $0.64 \mathrm{~kW}, 1.16 \mathrm{~kW}$, and $1.80 \mathrm{~kW}$, respectively with maximum LHR of 0.49 . Additionally, the study compared standalone DAC (S-DAC), and M-DAC system thermodynamically to investigate the feasibility of these systems from the viewpoints of temperature and relative humidity ranges, cooling potential $\left(Q_{p}\right)$, and coefficient of performance $(C O P)$. The S-DAC system showed temperature and relative humidity ranging from $39{ }^{\circ} \mathrm{C}$ to $48{ }^{\circ} \mathrm{C}$, and $35 \%$ to $66 \%$, respectively, with $Q_{p}$ and COP of $17.55 \mathrm{~kJ} / \mathrm{kg}$, and 0.37 , respectively. Conversely, the M-DAC system showed temperature and relative humidity ranging from $17{ }^{\circ} \mathrm{C}$ to $25^{\circ} \mathrm{C}$, and $76 \%$ to $98 \%$, respectively, with $Q_{p}$ and COP of $41.80 \mathrm{~kJ} / \mathrm{kg}$, and 0.87 , respectively. Additionally, the study investigated respiratory heat generation rate $\left(Q_{\text {res }}\right)$, and heat transfer rate $\left(Q_{\text {rate }}\right)$ by agricultural products at different temperature gradient $(\Delta T)$ and air velocity. The $Q_{\text {res }}$ and $Q_{\text {rate }}$ by the products were increased with $\Delta T$ and air velocity, respectively, thereby generating heat loads in the storage house. Therefore, the study suggests that the M-DAC system could be a potential AC option for agricultural storage application.
\end{abstract}

Keywords: evaporative cooling; desiccant dehumidification; agricultural storage; air conditioning; system performance 


\section{Introduction}

The world's population has grown rapidly over the past few decades and is predicted to move to about 9.8 billion by 2050 . Due to this population growth, the demand for food will rise about $70 \%$ by 2050 [1]. The agriculture sector plays a significant role in managing global food demand. Being an agriculture-dependent country, Pakistan produces 13.67 million tonnes of fruits and vegetables, but about $35-40 \%$ of total production is lost owing to post-harvest losses [2]. The post-harvest losses refer to degradation of quality as well as quantity of the agricultural products. One of the most important reasons for the postharvest losses is high amount of moisture content available in the agricultural products [3,4]. Moreover, several factors are responsible for the post-harvest losses as shown in Figure 1 [5]. After harvesting, fruits and vegetables perform respiration, transpiration, and ripening processes. These decay processes of agricultural products can be minimized by providing optimum storage conditions i.e., temperature and relative humidity [6]. Conventional storage techniques are equipped with refrigeration-based systems which consume huge amount of primary energy as well as degrading the environment by utilization of harmful refrigerants [7]. Moreover, these systems are incapable of providing the appropriate temperature and relative humidity conditions especially for agricultural products [8]. In this regard, alternative energy-efficient and environment-friendly options are available including evaporative cooling (EC), and desiccant air-conditioning (DAC) systems. The EC options are direct EC, indirect EC, and Maisotsenko cycle EC (MEC) systems i.e., an advanced form of the indirect EC [9]. The MEC system thermodynamically lowers the ambient air temperature by utilizing psychrometric accessible renewable energy [10]. Two thermodynamic operations which involve EC and heat transfer stipulate a cooling effect where ambient air almost approaches the dew point temperature rather than wet bulb temperature $[9,11]$. The MEC system has been investigated in literature for heating, ventilation, and air-conditioning applications [12-16]. However, the potential of the standalone EC systems is limited in humid areas [16,17]. Therefore, to overcome this limitation, the DAC system is an emerging option because of its potential to provide promising results in humid climates [18-20].

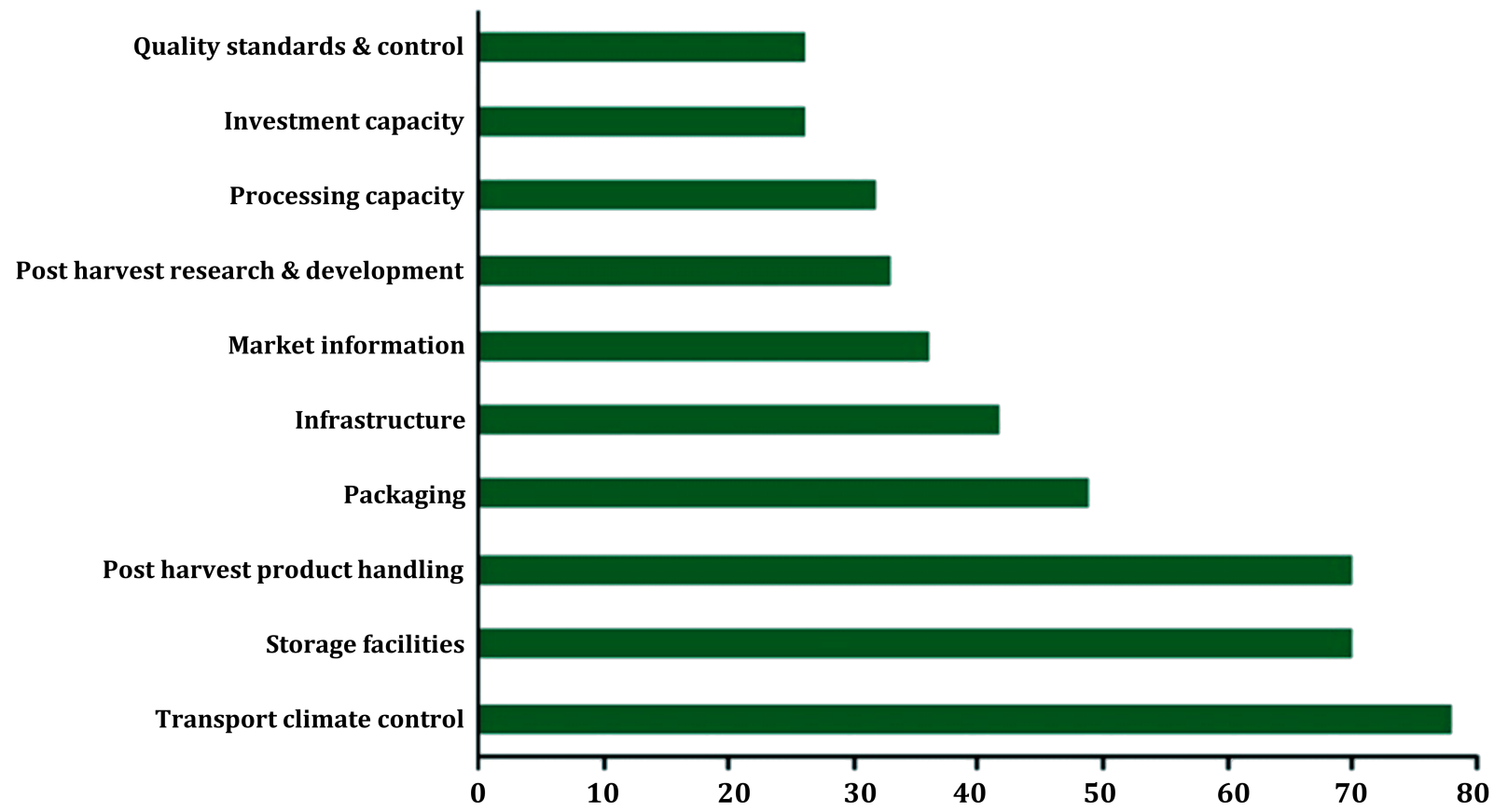

Figure 1. Major categories for causes of post-harvest losses, reproduced from ref. [5]

The main component of the DAC system is desiccant material which adsorb moisture from ambient/process air and thereby dehumidify the air. The adsorption/dehumidification 
and desorption/humidification processes are mainly dependent on characteristics of adsorbents [21-23]. The DAC systems are energy efficient as they are operated or regenerated with thermal energy that could be available through low-grade waste heat and renewable energy sources. Niu et al. [24] experimentally compared the energy saving potential of the DAC system with conventional refrigeration-based AC system. The study concluded that the DAC system had a maximum energy saving potential of about $58.9 \%$ [24]. Jia et al. [25] conducted an experimental study on the DAC system's ability to remove moisture from the air and its energy saving potential as compared with a conventional AC system. The study showed an energy saving potential of about $37.5 \%$ as compared with a conventional AC system [25]. Similar studies are reported in the literature which showed good energy saving potential by the DAC systems for various AC applications [26-29]. However, the standalone DAC (S-DAC) system i.e., without the integration of MEC with the DAC system, could not achieve appropriate temperature and relative humidity conditions particularly for agricultural product storage [9,30-32]. In this regard, an MEC system integrated with a DAC (M-DAC) system combines characteristics of both S-DAC and MEC systems, and thereby has potential to achieve sensible load via MEC and latent load through the DAC system [8]. The M-DAC system has been investigated in literature for various agricultural applications which involve greenhouse AC [33,34], livestock AC $[35,36]$, and poultry AC [37-40]. The M-DAC system has shown promising results for these agricultural applications.

In this study, a lab-scale solid silica gel-based DAC system was developed. The performance of the developed system was investigated thermodynamically, using various adsorption/dehumidification and desorption/regeneration cycles. Furthermore, performance of the developed system regarding energy consumption was investigated from the viewpoints of latent heat $\left(Q_{L}\right)$, sensible heat $\left(Q_{S}\right)$, and total heat $\left(Q_{T}\right)$ as well as latent heat ratio (LHR). The study proposed two kinds of AC system involving standalone DAC, and MEC-assisted DAC systems for potential application in agricultural product storage. A thermodynamic analysis was conducted for both systems to explore applicability of these systems considering temperature and relative humidity conditions, cooling potential $\left(Q_{p}\right)$, and coefficient of performance (COP). In addition, the study investigates respiratory heat generation rate $\left(Q_{\text {res }}\right)$ and heat transfer rate $\left(Q_{\text {rate }}\right)$ to investigate heat loads by the agricultural products.

\section{Temperature/Humidity Requirements for Agricultural Storage Application}

The storage and handling of agricultural products is one of the key issues of the 21st century because of the intricate mechanisms of transpiration, respiration as well as chilling injury. Appropriate temperature and relative humidity conditions are a primary concern to reduce post-harvest losses. The shelf life of agricultural products is a function of storage temperature. The storage temperature effect on the shelf life of fruits and vegetables is represented in Figure 2. A higher storage temperature reduces the shelf life of fruits and vegetables, while a lower storage temperature could increase the shelf life as represented in Figure 2. Moreover, the quality, composition, and texture of the products are significantly influenced by the temperature [41-43]. Figure 3 shows the effect of storage temperature on quality of peach, Boston-type lettuce, and asparagus. As the storage temperature increases the quality of the products decreases.

After harvesting, fruits and vegetables behave like living organisms and perform respiration processes according to Equation (1) available in ref. [46]. When ambient air oxygen combines with the product's conserved sugar/starch, carbon dioxide and water are generated, thereby releasing respiration heat. In order to minimize respiration rate, the agricultural products should be stored at low oxygen level. However, as the temperature rises, the respiration rate increases, thereby reducing the shelf life of the product. The influence of temperature on respiration rate by some fruits and vegetables is shown in Figure 4. The effect of temperature on some fruits is shown in Figure 4a, which shows respiration rate increases with temperature. Similarly, the effect of temperature on vegetables in 
Figure $4 \mathrm{~b}$ shows that the respiration rate increases with temperature. This respiration rate increases heat i.e., respiratory heat in a storage house. The quantity of moisture present in the ambient air, expressed as relative humidity, is the primary driver of water loss from harvested goods. The agricultural products preserve their nutritional quality, flavour, and appearance at high relative humidity. In contrast, shrivelling occurs at low relative humidity ranges because of excessive transpiration $[47,48]$. In this regard, the optimum temperature and relative humidity conditions for fruits and vegetables are available in refs. $[19,49]$ ranging from $-5^{\circ} \mathrm{C}$ to $25^{\circ} \mathrm{C}$, and $85 \%$ to $95 \%$, respectively. Figure 5 represents the optimum temperature and relative humidity zones for storage of fruits and vegetables with the climatic conditions of Multan.

$$
\mathrm{C}_{6} \mathrm{H}_{12} \mathrm{O}_{6}+6 \mathrm{O}_{2} \rightarrow+6 \mathrm{CO}_{2}+6 \mathrm{H}_{2} \mathrm{O}+\text { respiration heat }
$$
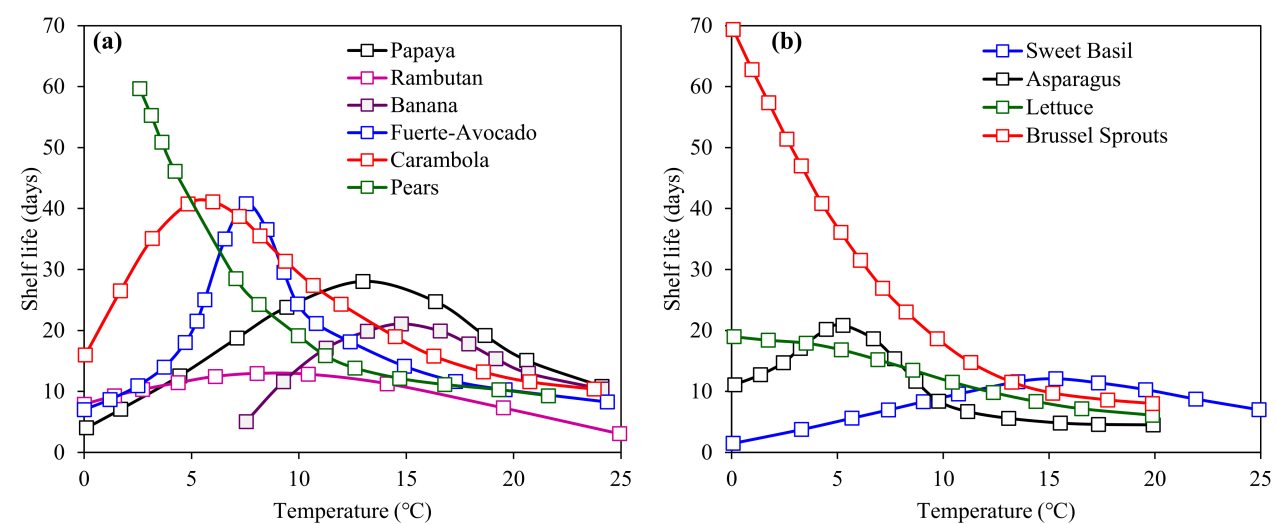

Figure 2. Effect of storage temperature on shelf life of some (a) fruits, and (b) vegetables, reproduced from ref. [44].
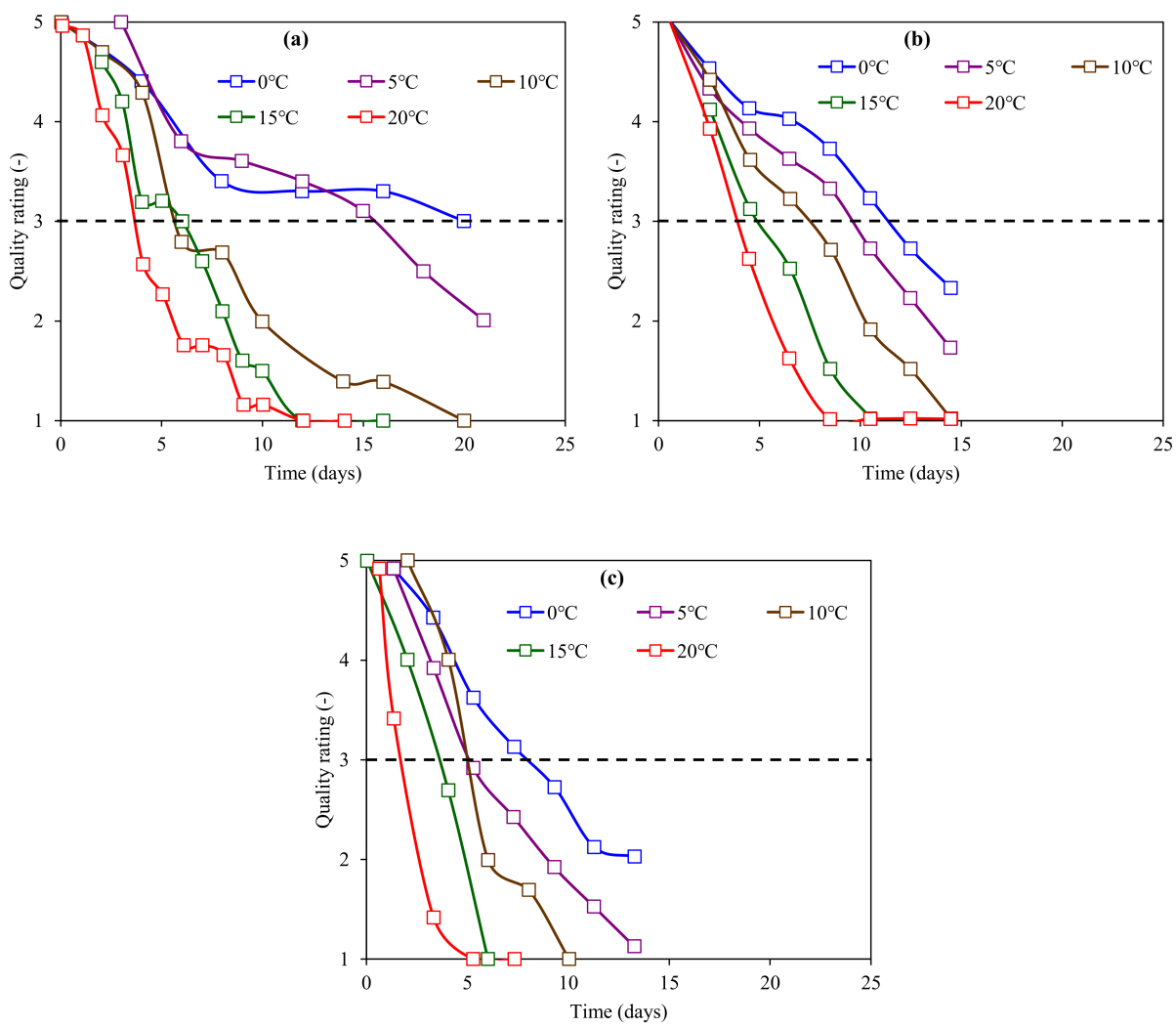

Figure 3. Effect of temperature on the quality (a) peach, (b) Boston-type lettuce, and (c) asparagus. The dotted lines represent acceptable limits of the product, reproduced from ref. [45]. 

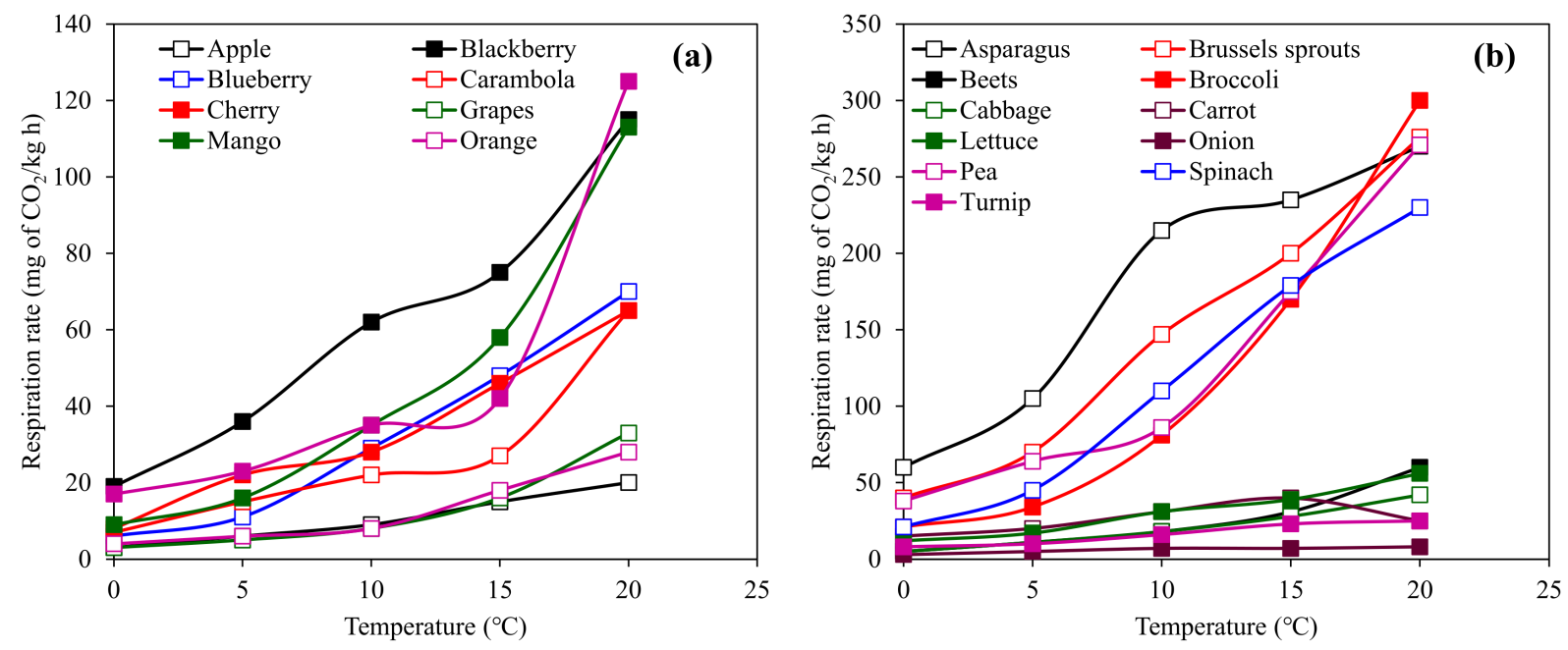

Figure 4. Effect of temperature on respiration rate of some (a) fruits, and (b) vegetables, data obtained from ref. [50].

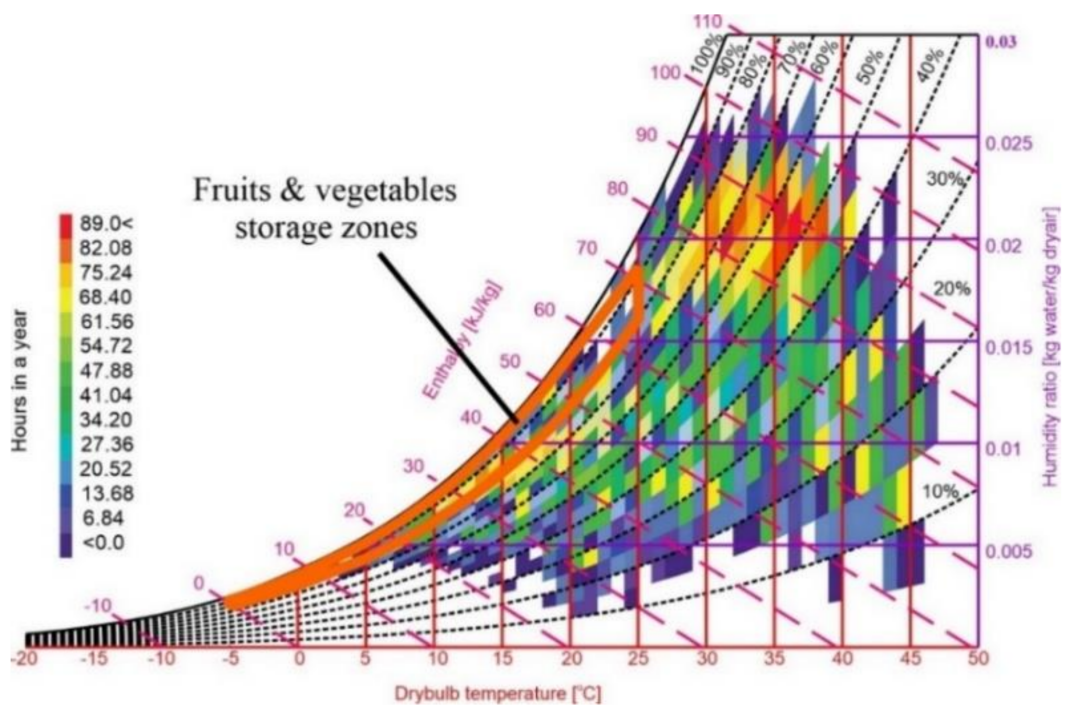

Figure 5. Optimum temperature and humidity zones for storage of fruits and vegetables at climatic conditions of Multan.

\section{Proposed Systems}

\subsection{Standalone Desiccant Air-Conditioning (S-DAC) System}

Referring to the Figure 6a, components of the S-DAC system consist of desiccant block, a sensible heat exchanger (SHX), and a heating source. Ambient/process air is entered into the block during the adsorption process and gets dehumidified, which thereby increases the temperature of the air due to the release of the heat of adsorption. After that, the dehumidified air is entered into the SHX which ideally reduces the temperature to ambient air temperature. During the desorption process of the S-DAC system, ambient air was utilized as a return air and directed towards the SHX, which thereby gets heated. Then, this processed heated air enters a heat source which can be operated with thermal energy options like low-grade waste heat as well as renewable energy options such as solar thermal heat and biogas/biomass, etc. In the end, this heated air is directed to a desiccant block which carries away water vapours from the desiccant material to regenerate and hence remove humid air. 


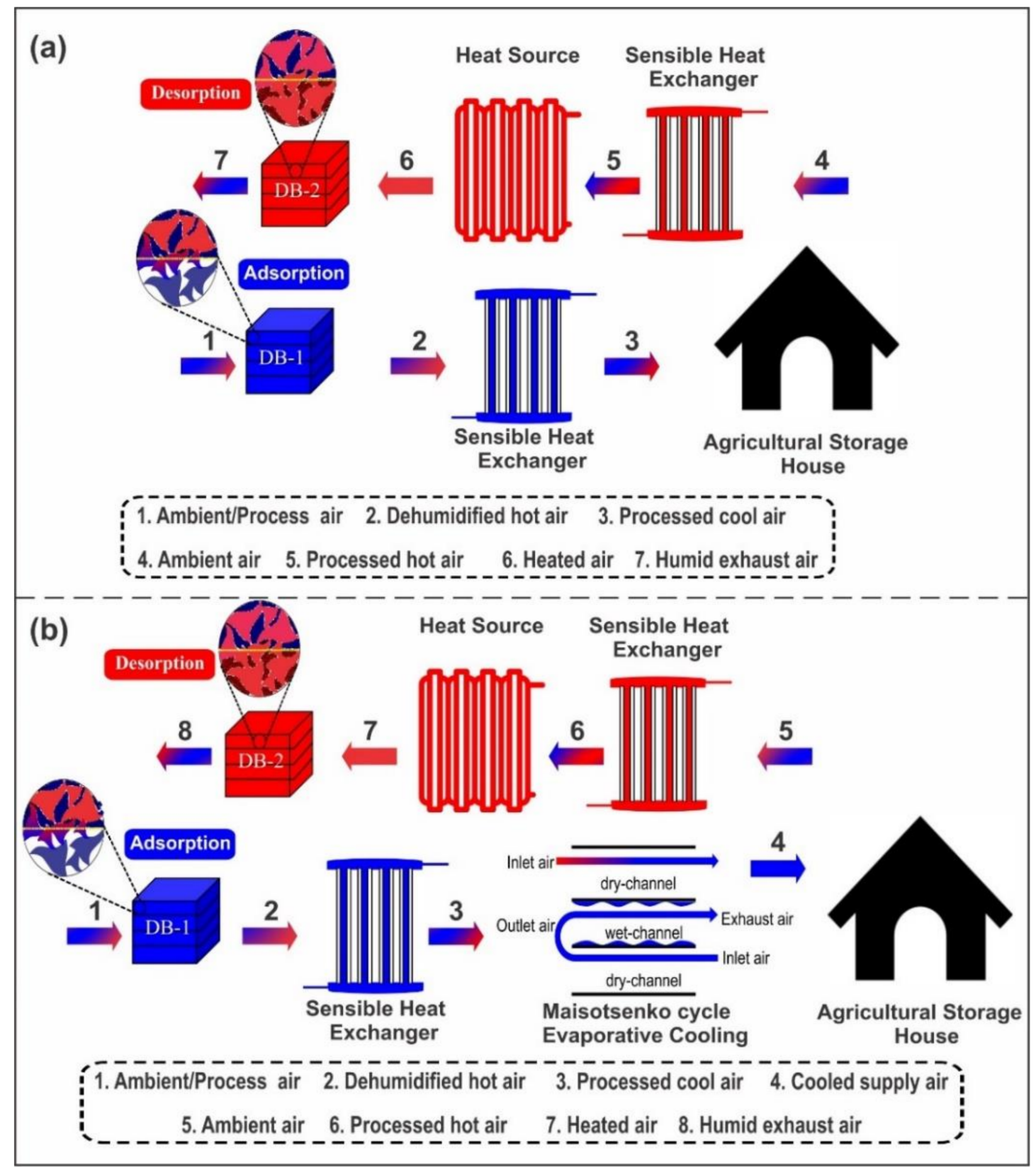

Figure 6. Working scheme of proposed (a) standalone DAC (S-DAC), and (b) M-cycle integrated DAC (M-DAC) system.

\subsection{M-Cycle Integrated Desiccant Air-Conditioning (M-DAC) System Collection}

Referring to Figure $6 \mathrm{~b}$, components of the M-DAC system consist of desiccant block, SHX, MEC, and a heating source. Ambient air is directed into the block during the adsorption process of the M-DAC system and gets dehumidified, thereby increasing the temperature due to the release of the heat of adsorption. After that, the dehumidified air is directed towards the SHX which decreases the process air temperature to nearly that of the ambient air without change in the humidity ratio. This cooled process air is further directed towards the MEC which lowers the process air temperature sensibly which could be supplied to the agriculture storage house. During the desorption process of the M-DAC system, ambient air, as a return air, is employed and enters the SHX, which thereby gets heated. Then, this processed heated air is directed towards the heat source which can be operated with thermal energy options like low-grade waste heat and renewable energy options such as solar thermal heat and biogas/biomass, etc. In the end, this heated air 
is directed towards desiccant block which carries away water vapours from the block to regenerate it and hence remove the humid air.

\section{Materials and Methods}

\subsection{Experimental Setup}

The solid silica gel-based DAC system was developed at laboratory scale. The experimental setup was mainly consisted of solid silica gel, sieves, heat exchanger (i.e., fan heater), temperature, relative humidity, pressure, and velocity (anemometer) measuring sensors. Figure 7a shows the photographic view of the developed experimental setup. The sieves are fabricated by using polyacrylic plastic material frame and mesh to support the material and easy crossing of air. A total of 18 sieves were used to develop the desiccant unit and each sieve has a dimension of $220 \mathrm{~mm} \times 145 \mathrm{~mm} \times 3 \mathrm{~mm}$ and carrying $\sim 68 \mathrm{~g}$ of silica gel. These sieves are stacked over each other to form a desiccant unit and then insulated on the sides. The important parameters for desiccant unit and silica gel used in this study is shown in Table 1. The fan was used to continuously throw the process air at velocity of about $3.5 \mathrm{~m} / \mathrm{s}$, resulting in a mass flow rate $\left(\dot{m}_{a}\right)$ of about $0.14 \mathrm{~kg} / \mathrm{s}$. The temperature, relative humidity, and pressure sensors were placed at the inlet and outlet sides of the desiccant unit to measure the experimental conditions. The measurement range and absolute accuracy for temperature, relative humidity, pressure, and velocity sensors is about $-40{ }^{\circ} \mathrm{C}$ to $80{ }^{\circ} \mathrm{C} ; \pm 2{ }^{\circ} \mathrm{C}, 0 \%$ to $100 \% ; \pm 5 \%, 75 \mathrm{kPa}$ to $110 \mathrm{kPa} ; \pm 0.3 \mathrm{kPa}$, and $0.3 \mathrm{~m} / \mathrm{s}$ to $30 \mathrm{~m} / \mathrm{s} ; \pm 1.5 \mathrm{~m} / \mathrm{s}$, respectively.
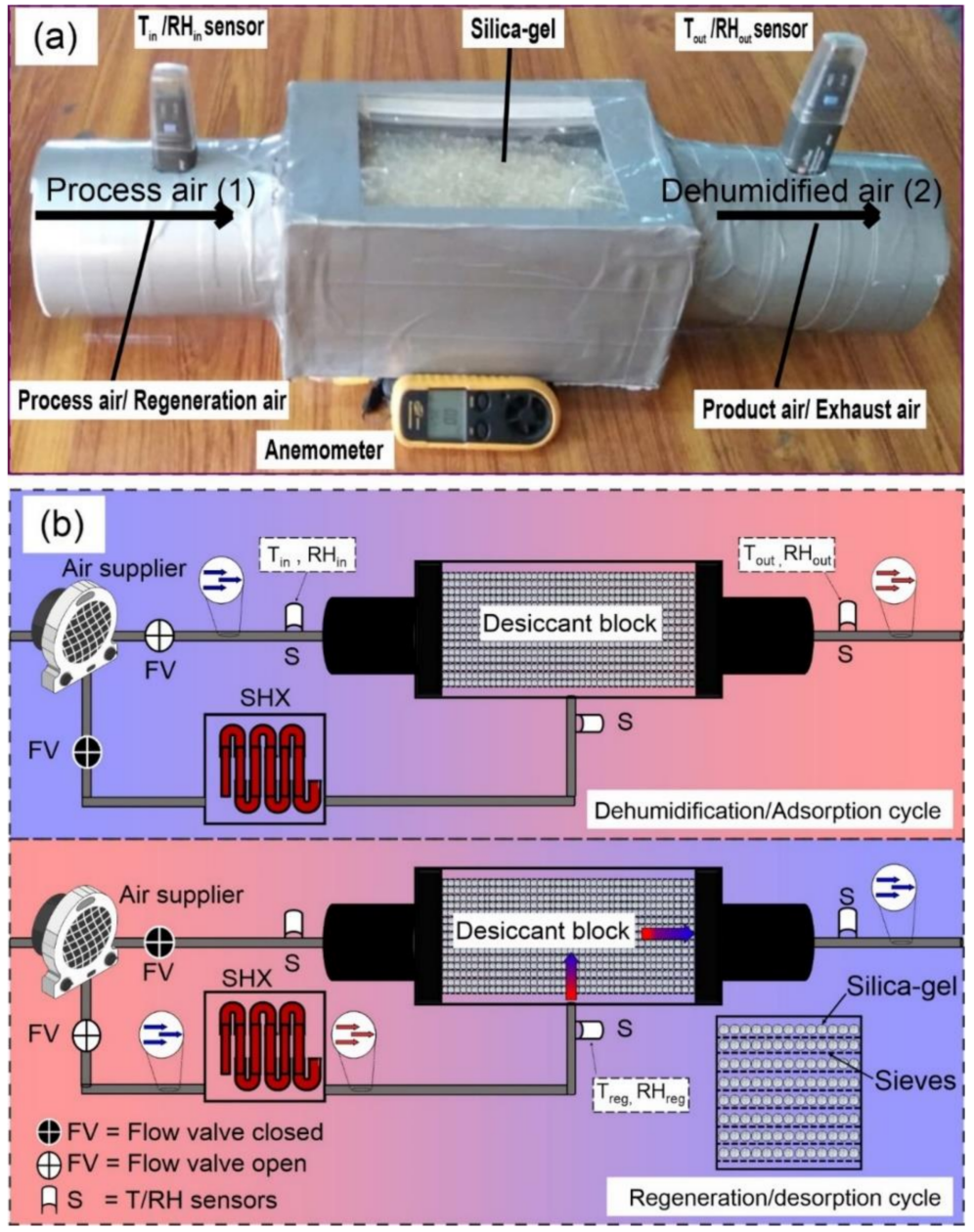

Figure 7. (a) Photographic view of the developed experimental system, and (b) working scheme of the developed experimental system. 
Table 1. Important parameters of desiccant unit and silica gel used in this study.

\begin{tabular}{cccc}
\hline Parameters & Symbol & Value & Unit \\
\hline Width & Parameters related to desiccant unit & \\
\hline Length & $\mathrm{W}$ & 0.145 & $\mathrm{~m}$ \\
\hline Height & $\mathrm{L}$ & 0.220 & $\mathrm{~m}$ \\
\hline Total silica gel & $\mathrm{H}$ & 0.045 & $\mathrm{~m}$ \\
\hline & & 1.22 & $\mathrm{~kg}$ \\
\hline Molar mass & Parameters related to silica gel & $\mathrm{g} / \mathrm{kg}$ \\
\hline Bulk density & $\mathrm{M}$ & 60.08 & $\mathrm{~kg} / \mathrm{m}$ \\
\hline Specific heat capacity & $\rho_{b}$ & 919.5 & $\mathrm{~kJ} / \mathrm{kg} \cdot \mathrm{K}$ \\
\hline Specific surface area & $\mathrm{C}_{\mathrm{p}}$ & 0.85 & $\mathrm{~m} / \mathrm{g}$ \\
\hline Pore size & $\mathrm{SSA}$ & $750-850$ & $\mathrm{~nm}$ \\
\hline Heat of adsorption & $\varphi$ & $2-2.6$ & $\mathrm{~kJ} / \mathrm{kg}$ \\
\hline Thermal conduction & $\Delta \mathrm{h}$ & 2800 & $\mathrm{~W} / \mathrm{m} \cdot \mathrm{K}$ \\
\hline
\end{tabular}

The experimental process is divided into two stages: desorption/regeneration and adsorption/dehumidification. Figure $7 \mathrm{~b}$ shows a schematic representation of the developed experimental system. During the regeneration process, hot air (achieved by heat exchanger) is supplied to the desiccant unit to primarily reactivate the adsorbent. After that, the dehumidification process commences, and process air is directed to the desiccant unit and moisture adsorbs on the material's surface because of its hygroscopic nature, thereby increasing the temperature of process air due to the release of heat of adsorption [51]. In this study, four desorption as well as adsorption cycles were conducted at different regeneration temperatures. The regeneration temperature was set at $68^{\circ} \mathrm{C}, 69.2{ }^{\circ} \mathrm{C}, 70.5^{\circ} \mathrm{C}$, and $72.6^{\circ} \mathrm{C}$ for cycles 1, 2, 3 and 4, respectively. Figure 8 shows the performance of the experimental system at different regeneration temperatures by conducting various desorption/adsorption cycles. The system has shown maximum dehumidification potential at higher regeneration temperature of $72.6{ }^{\circ} \mathrm{C}$. In this regard, the study focuses on the desorption and adsorption cycle- 4 to thermodynamically explore the performance of the system.

Ideally, the adsorption process follows isenthalpic behaviour, which means that the heat of water vapor condensation following the vapor stage to liquid stage is the same as the heat of adsorption. However, experimental studies have shown that the heat of adsorption is higher than the ideal adsorption heat because of the isosteric heat of adsorption [51,52]. The difference between an ideal isenthalpic line and the actual dehumidification line is mainly due to the type of adsorption mechanism and interaction between adsorbent pairs. Figure 9 represents the psychrometric behaviour of the ideal and experimental dehumidification line and cyclic behaviour of proposed DAC systems. The points 1-8 were calculated by considering the experimental inlet and outlet conditions.

\subsection{Data Reduction}

The experimental data of the developed DAC based on various desorption and adsorption cycles were obtained to investigate the performance thermodynamically. The inlet and outlet air conditions of both desorption and adsorption cycles were measured during the experiments. After that, Equation (2) was used to calculate the output air condition of the SHX [19,53]. The modelled Equation (3) of the MEC was used to calculate the performance of the MEC system [36,54]. Ambient air as a return air was used to increase the air 
temperature to some extent by Equation (4). Maximum desorption potential $\left(\Delta X_{d e s}\right)$ and adsorption $\left(\Delta X_{a d s}\right)$ potential were calculated from Equations (5) and (6) [31].

$$
\begin{gathered}
T_{3, D B}=T_{2, D B}-\varepsilon_{S H X}\left(T_{2, D B}-T_{1, D B}\right) \\
T_{4, D B}=6.70+0.2630\left(T_{3, D B}\right)+0.5298\left(X_{3}\right) \\
T_{6, D B}=T_{5, D B}+\varepsilon_{S H X}\left(T_{2, D B}-T_{5, D B}\right) \\
\Delta X_{d e s}=X_{\text {in, des }}-X_{o u t, d e s} \\
\Delta X_{a d s}=X_{\text {in, ads }}-X_{o u t, a d s}
\end{gathered}
$$

where, the subscripts 1-6, and $D B$, are process air conditions represented in Figure 6, and dry-bulb, respectively. $T$ is air temperature $\left({ }^{\circ} \mathrm{C}\right), \varepsilon_{S H X}$ is the effectiveness of sensible heat exchanger defined by the American Society of Heating, Refrigerating, and Air-Conditioning Engineers (ASHRAE) [46], $X$ is humidity ratio (g/kg-DA), $\Delta X_{\text {des }}$ is desorption potential (g/kg-DA), $\Delta X_{a d s}$ is adsorption potential (g/kg-DA), $X_{i n, \text { des }}$ is inlet humidity ratio during desorption process $\left(\mathrm{g} / \mathrm{kg}\right.$-DA), $X_{\text {out,des }}$ is outlet humidity ratio after desorption process (g/kg-DA), $\Delta X_{a d s}$ is adsorption potential (g/kg-DA), $X_{i n, a d s}$ is inlet humidity ratio during adsorption process $(\mathrm{g} / \mathrm{kg}-\mathrm{DA})$, and $X_{\text {out, ads }}$ is outlet humidity ratio after adsorption process (g/kg-DA), respectively.

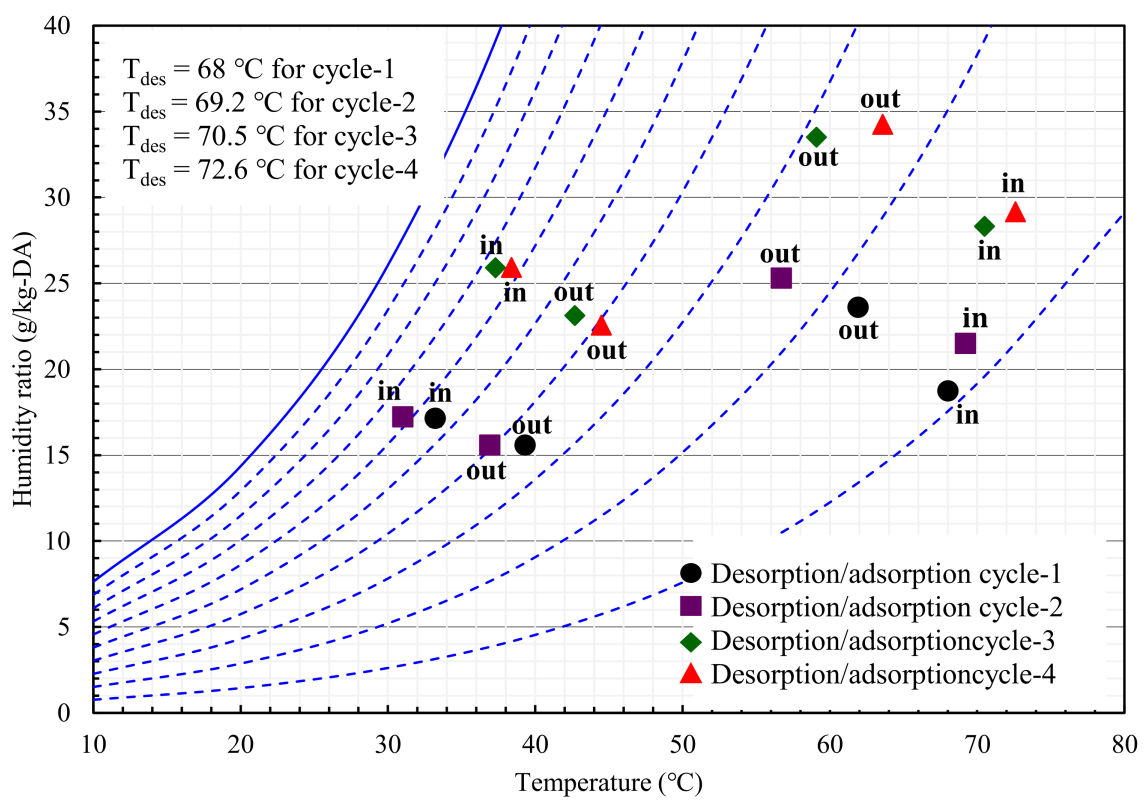

Figure 8. Performance of the experimental system at different regeneration temperatures by conducting various desorption/adsorption cycles.

The performance of the developed desiccant unit regarding energy consumption can be evaluated by latent heat ratio (LHR) [55]. The LHR is the ratio of latent heat consumed to the total energy consumed by the system which is given in Equation (7). The total energy $\left(Q_{T}\right)$ consumed by the system was calculated from Equations (8)-(11) based on sensible heat $\left(Q_{S}\right)$, latent heat $\left(Q_{L}\right)$, and electricity consumed by the fan $\left(Q_{F}\right)$ to supply the process air [55]. However, Equations (12)-(14) were used to calculate cooling potential $\left(Q_{p}\right)$ by the proposed S-DAC and M-DAC system, respectively. Similarly, Equations (13) and (14) were used to calculate the coefficient of performance (COP) by the proposed S-DAC, and M-DAC system, respectively. The air enthalpy was calculated by Equation (15) [46].

$$
L H R=\left(\frac{Q_{L}}{Q_{T}}\right)
$$




$$
\begin{gathered}
Q_{T}=Q_{S}+Q_{L}+Q_{F} \\
Q_{S}=\dot{m}_{a} C_{p}\left(T_{\text {des }, \text { in }}-T_{\text {des }, \text { out }}\right) \\
Q_{L}=\dot{m}_{a} \Delta X_{a d s} \gamma=\dot{m_{a}}\left(h_{\text {ads }, \text { in }}-h_{\text {ads }, \text { out }}\right) \\
Q_{F}=\frac{\dot{V}_{\text {air }} d P}{\varepsilon_{F}} \\
Q_{p, S-D A C}=h_{1}-h_{3} \\
Q_{p, M-D A C}=h_{1}-h_{4} \\
C_{S-D A C}=\frac{\dot{m_{a}}}{\dot{m}_{a}}\left(\frac{\text { Cooling potential }}{\text { Heat input }}\right)=\frac{\dot{m}_{a}}{\dot{m}_{a}}\left(\frac{h_{1}-h_{3}}{h_{6}-h_{5}}\right) \\
\dot{C O P}_{M-D A C}=\frac{\dot{m}_{a}}{\dot{m}_{a}}\left(\frac{\text { Cooling potential }}{\text { Heat input }}\right)=\frac{\dot{m}_{a}}{\dot{m}_{a}}\left(\frac{h_{1}-h_{3}}{h_{7}-h_{6}}\right) \\
h=1.006 T_{D B}+X\left(2501+1.86 T_{D B}\right)
\end{gathered}
$$

where, $L H R$ is latent heat ratio (-), $Q_{L}$ is latent heat consumption $(\mathrm{kW}), Q_{T}$ is total heat consumption $(\mathrm{kW}), Q_{S}$ is sensible heat consumption $(\mathrm{kW}), Q_{F}$ is electricity consumed by fan $(\mathrm{kW}), \dot{m}_{a}$ is mass flow rate $(\mathrm{kg} / \mathrm{s}), C_{p}$ is specific heat capacity of air $(\mathrm{kJ} / \mathrm{kg} \mathrm{K})$, $T_{\text {des, in }}$ is the inlet temperature of desorption process $(\mathrm{K}), T_{\text {des,out }}$ is the outlet temperature of the desorption process $(\mathrm{K}), \Delta X_{a d s}$ is adsorption potential $(\mathrm{g} / \mathrm{kg}-\mathrm{DA}), \gamma$ is latent heat of vaporization with respect to temperature $(\mathrm{kJ} / \mathrm{kg}), h_{a d s, \text { in }}$ is inlet enthalpy of adsorption process $(\mathrm{kJ} / \mathrm{kg}), h_{\text {ads,out }}$ is outlet enthalpy of adsorption process $(\mathrm{kJ} / \mathrm{kg}), \dot{V}_{\text {air }}$ is volume flow rate $\left(\mathrm{m}^{3} / \mathrm{s}\right), d P$ is pressure drop $(\mathrm{kPa})$, and $\varepsilon_{F}$ is efficiency of the fan taken as $70 \%$. The subscripts 1, 3, 4, 5, 6, 7 S-DAC, and $M-D A C$, and $D B$ refer to air states as shown in Figure 6, standalone desiccant air-conditioning, M-cycle integrated desiccant air-conditioning system, and dry bulb, respectively. $Q_{p}$ is cooling potential $(\mathrm{kJ} / \mathrm{kg}), h$ is air enthalpy $(\mathrm{kJ} / \mathrm{kg})$, and COP is coefficient of performance (-), respectively.
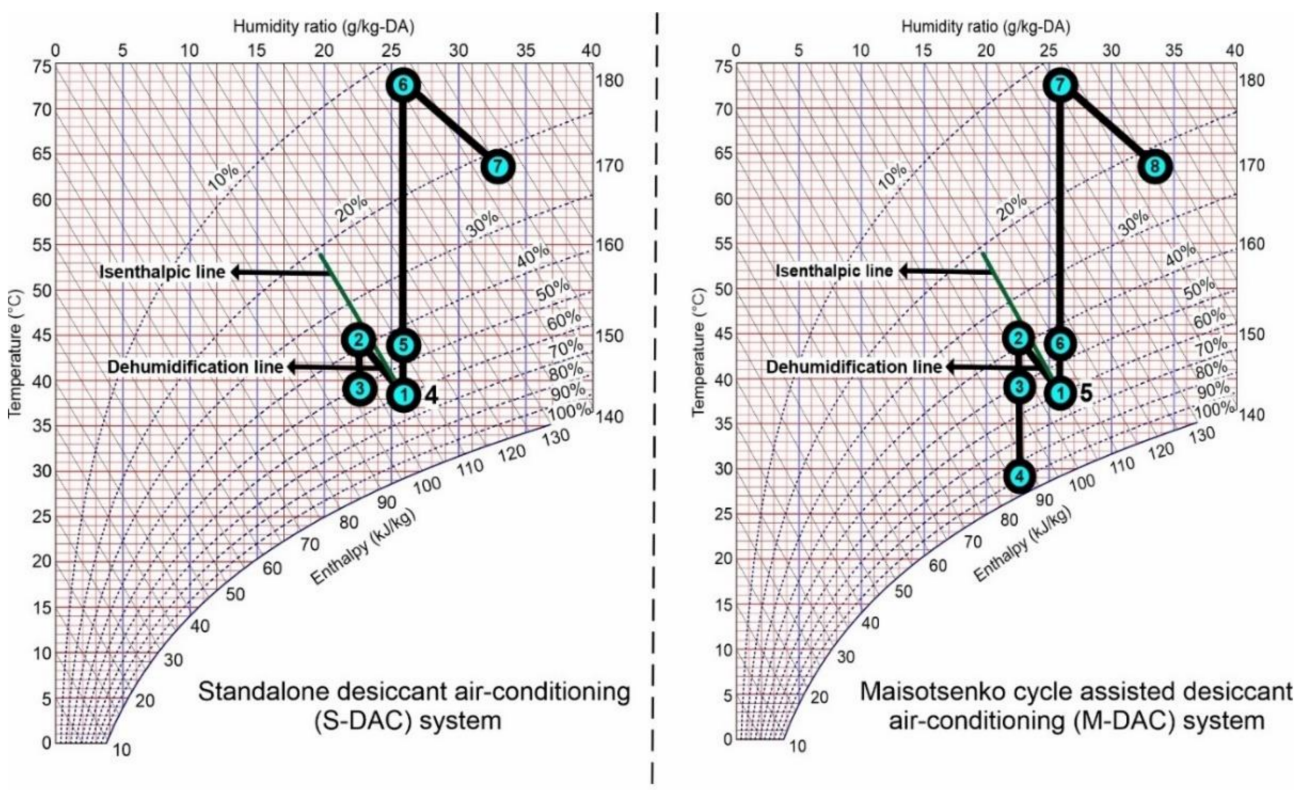

Figure 9. Ideal and experimental dehumidification lines and cyclic behaviour of the proposed DAC systems on Psychrometric/Mollier diagram.

\subsection{Uncertainty Analysis}

In the experimentation process, there are always errors in calculating/measuring variables due to the inaccuracy of instruments, design limitations, ambient conditions, 
observations, human errors, and other associated important factors. After experiments, an uncertainty analysis was performed to determine the level of uncertainty in estimating the variables (temperature, relative humidity). Estimating the experimental uncertainty gives confidence in the calculated results. The method is named as the root of the sum of square methods and Equation (17) is used to measure the uncertainty [56-58].

$$
\sigma_{R}=\sqrt{\left(\frac{\partial R}{\partial N_{1}} \alpha_{1}\right)^{2}+\left(\frac{\partial R}{\partial N_{2}} \alpha_{2}\right)^{2}+\cdots+\left(\frac{\partial R}{\partial N_{n}} \alpha_{N}\right)^{2}}
$$

where, $\sigma_{R}$ is the total uncertainty (\%) and $\alpha_{1}-\alpha_{N}$ represent the uncertainty in independent variables, $N_{1}-N_{n}$ represent the independent variables $R$ is given a function of the independent variable. Table 2 shows the uncertainty analysis of various parameters used in this study.

Table 2. Uncertainty analysis of various parameters used in this study.

\begin{tabular}{ccc}
\hline Parameter & Symbol & Value \\
\hline Temperature & $T$ & $\pm 2.6 \%$ \\
Relative humidity & $R H$ & $\pm 5.1 \%$ \\
Pressure & $P$ & $\pm 1.6 \%$ \\
Velocity & $V$ & $\pm 3.4 \%$ \\
Humidity ratio & $X$ & $\pm 1.6 \%$ \\
Enthalpy & $h$ & $\pm 2.9 \%$ \\
Cooling potential & $Q_{p}$ & $\pm 5.1 \%$ \\
Coefficient of performance & $C O P$ & $\pm 2.7 \%$ \\
Sensible heat & $Q_{S}$ & $\pm 2.2 \%$ \\
Latent heat & $Q_{L}$ & $\pm 5.4 \%$ \\
Latent heat ratio & $L H R$ & $\pm 5.37 \%$ \\
\hline
\end{tabular}

\subsection{Heat Load Calculations for Agricultural Storage Application}

The storage of agricultural products offers considerable challenges as they generate heat during storage by consuming oxygen and emitting carbon dioxide, water vapours and heat transfer between product and ambient air. The respiratory process varies with temperature as well as type of the product. Becker et al. [59] developed a relationship of measuring respiratory heat generation rate as a function of the temperature of the agricultural product, given by Equation (18). Furthermore, heat is removed from the product due to heat transfer between product and ambient air which was calculated by Equation (19) [60].

$$
\begin{gathered}
Q_{\text {res }}=\frac{10.7 f}{3600}\left(\frac{9 T}{5}+32\right)^{g} \\
Q_{\text {rate }}=h_{s} \times A_{s} \times \Delta T=h_{s} \times A_{s} \times\left(T_{s}-T_{a}\right)
\end{gathered}
$$

where, $Q_{\text {res }}$ is respiratory heat generation rate $(\mathrm{W} / \mathrm{kg}), T$ is temperature of the product $\left({ }^{\circ} \mathrm{C}\right)$, $f$ and $g$ are respiratory coefficients depending upon the agricultural product. Table 3 shows the respiratory coefficients of some selected fruits and vegetables. $Q_{\text {rate }}$ is heat transfer rate from the product $(\mathrm{W}), h_{s}$ is surface heat transfer coefficient $\left(\mathrm{W} / \mathrm{m}^{2}{ }^{\circ} \mathrm{C}\right), A_{S}$ is surface area covered by a product $\left(\mathrm{m}^{2}\right), \Delta T$ is temperature difference between product surface and ambient air $\left({ }^{\circ} \mathrm{C}\right), T_{s}$ is surface temperature of product $\left({ }^{\circ} \mathrm{C}\right)$, and $T_{a}$ ambient or surrounding air temperature $\left({ }^{\circ} \mathrm{C}\right)$. The $h_{s}$ vary with velocity of ambient air, product orientation and geometry. Several studies have investigated the $h_{s}$ against ambient air velocity, and the $A_{s}$ for various agricultural products presented in Table 4. In this principle, behavior of the $Q_{\text {rate }}$ from the agricultural products has been explored by considering literature data of $h_{s}$ against air velocity, and $A_{s}$. 
Table 3. Respiratory coefficients of some fruits and vegetables, reproduced from ref. [59].

\begin{tabular}{ccc}
\hline \multirow{2}{*}{ Product } & \multicolumn{2}{c}{ Respiration Coefficients } \\
\cline { 2 - 3 } & $f$ & $g$ \\
\hline Apple & Fruits & \\
Grape & $5.687 \times 10^{-4}$ & 2.5977 \\
Orange & $7.056 \times 10^{-5}$ & 3.033 \\
Pear & $2.8050 \times 10^{-4}$ & 2.6840 \\
Tomato & $6.3614 \times 10^{-5}$ & 3.2037 \\
& $2.0074 \times 10^{-4}$ & 2.8350 \\
\hline Cabbage & Vegetables \\
Carrot & $6.0803 \times 10^{-4}$ & 2.6183 \\
Onion & 0.050018 & 1.7926 \\
Potato & $3.668 \times 10^{-4}$ & 2.538 \\
\hline
\end{tabular}

Table 4. Surface heat transfer coefficient with air velocity, and surface area for some fruits and vegetables.

\begin{tabular}{|c|c|c|c|c|}
\hline Product & $\begin{array}{l}\text { Air Velocity } \\
(\mathrm{m} / \mathrm{s})\end{array}$ & $\begin{array}{c}\text { Surface Heat Transfer } \\
\text { Coeff., } h_{s}\left(\mathrm{~W} / \mathrm{m}^{2}{ }^{\circ} \mathrm{C}\right)\end{array}$ & $\begin{array}{c}\text { Surface Area, } A_{s} \\
\left(\mathrm{~m}^{2}\right)\end{array}$ & Reference \\
\hline \multicolumn{5}{|c|}{ Fruits } \\
\hline \multirow{6}{*}{ Apple } & 0 & 11.1 & \multirow{6}{*}{0.0116} & \multirow{6}{*}[60,61]{} \\
\hline & 0.39 & 17 & & \\
\hline & 0.91 & 27.3 & & \\
\hline & 2 & 45.3 & & \\
\hline & 5.1 & 53.4 & & \\
\hline & 1 & 30.7 & & \\
\hline \multirow{4}{*}{ Grape } & 1.25 & 33.8 & \multirow{4}{*}{0.0008} & \multirow{4}{*}[60,62,63]{} \\
\hline & 1.5 & 37.8 & & \\
\hline & 1.75 & 40.7 & & \\
\hline & 2 & 42.3 & & \\
\hline \multirow{3}{*}{ Orange } & 0.11 & 66.4 & \multirow{3}{*}{0.01622} & \multirow{3}{*}[60,64,65]{} \\
\hline & 0.33 & 69.3 & & \\
\hline & 1 & 12.6 & & \\
\hline \multirow{4}{*}{ Pear } & 1.25 & 14.2 & \multirow{4}{*}{0.007598} & \multirow{3}{*}[60,62,66]{} \\
\hline & 1.5 & 15.8 & & \\
\hline & 1.75 & 16.1 & & \\
\hline & 2 & 19.5 & & \multirow{6}{*}[60,62,67]{} \\
\hline \multirow{5}{*}{ Tomato } & 1 & 10.9 & \multirow{5}{*}{0.008} & \\
\hline & 1.25 & 13.1 & & \\
\hline & 1.5 & 13.6 & & \\
\hline & 1.75 & 14.9 & & \\
\hline & 2 & 17.3 & & \\
\hline \multicolumn{5}{|c|}{ Vegetables } \\
\hline Cabbage & 0.431 & 53.8033 & 0.000415 & {$[68,69]$} \\
\hline Carrot & 0.0158 & 547 & 0.007758 & {$[70,71]$} \\
\hline Onion & 0.431 & 54.6125 & 0.001404 & {$[61,72]$} \\
\hline Potato & 0.431 & 39.0599 & 0.000134 & {$[69,73]$} \\
\hline
\end{tabular}

\section{Results and Discussion}

The performance of the desiccant unit was examined thermodynamically for various desorption and adsorption cycles. Figure 10 shows experimental desorption and adsorption cycles profiles of temperature for the developed DAC system at different desorption temperatures $\left(T_{d e s}\right)$. The switching time of 1:1 (equal time for both stages) was considered for the desorption and adsorption cycles. These cycles were conducted to explore optimum switching time, and desorption/regeneration temperature for higher coefficient 
of performance and maximum adsorption potential. The temperature cycles represent that $20 \mathrm{~min}: 20 \mathrm{~min}, 30 \mathrm{~min}: 30 \mathrm{~min}, 45 \mathrm{~min}: 45 \mathrm{~min}$, and $60 \mathrm{~min}: 60 \mathrm{~min}$ was set for the desorption and adsorption cycle 1, 2, 3 and 4, respectively. The outlet temperature (after adsorption process) ranges from $39^{\circ} \mathrm{C}$ to $62^{\circ} \mathrm{C}$ (cycle-1), $37^{\circ} \mathrm{C}$ to $57^{\circ} \mathrm{C}$ (cycle-2), $43{ }^{\circ} \mathrm{C}$ to $59^{\circ} \mathrm{C}$ (cycle-3), and $44{ }^{\circ} \mathrm{C}$ to $63^{\circ} \mathrm{C}$ (cycle-4), respectively. The process air temperature increases due to release of heat of adsorption. Figure 11 shows experimental desorption and adsorption cycles profiles of relative humidity for the DAC system. The outlet relative humidity (after adsorption process) ranges from $17 \%$ to $35 \%$ (cycle- 1 ), $22 \%$ to $40 \%$ (cycle-2), $23 \%$ to $43 \%$ (cycle-3), and $20 \%$ to $38 \%$ (cycle- 4 ), respectively.

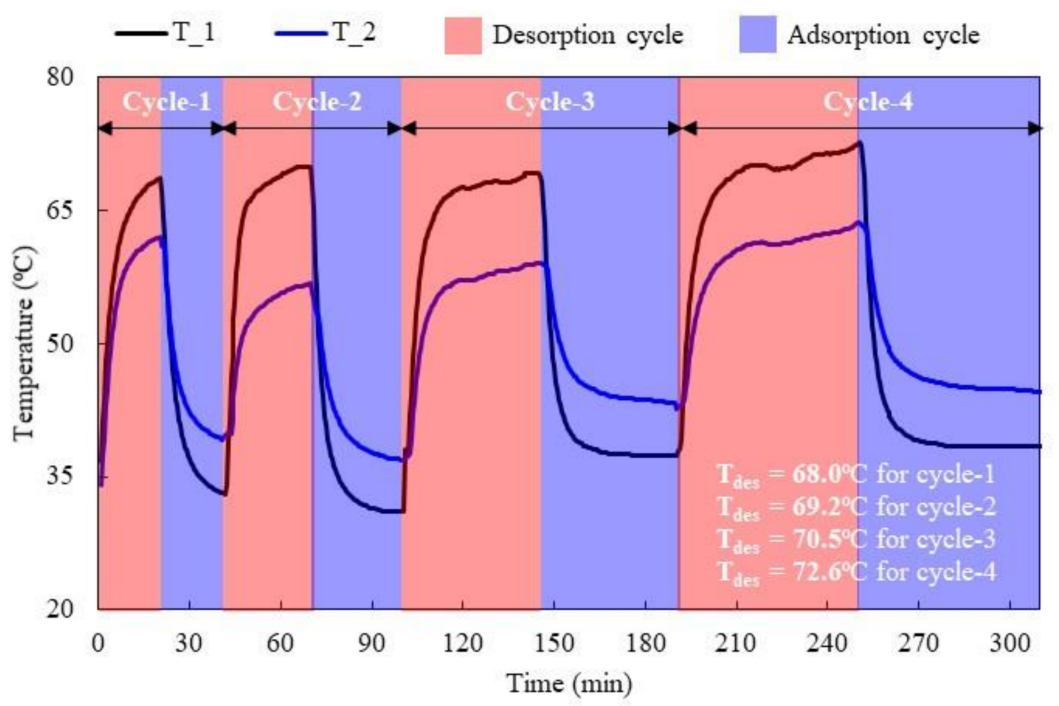

Figure 10. Experimental desorption/regeneration and adsorption/dehumidification cycle profiles of temperature for the DAC system at different desorption temperature $\left(T_{d e s}\right)$.

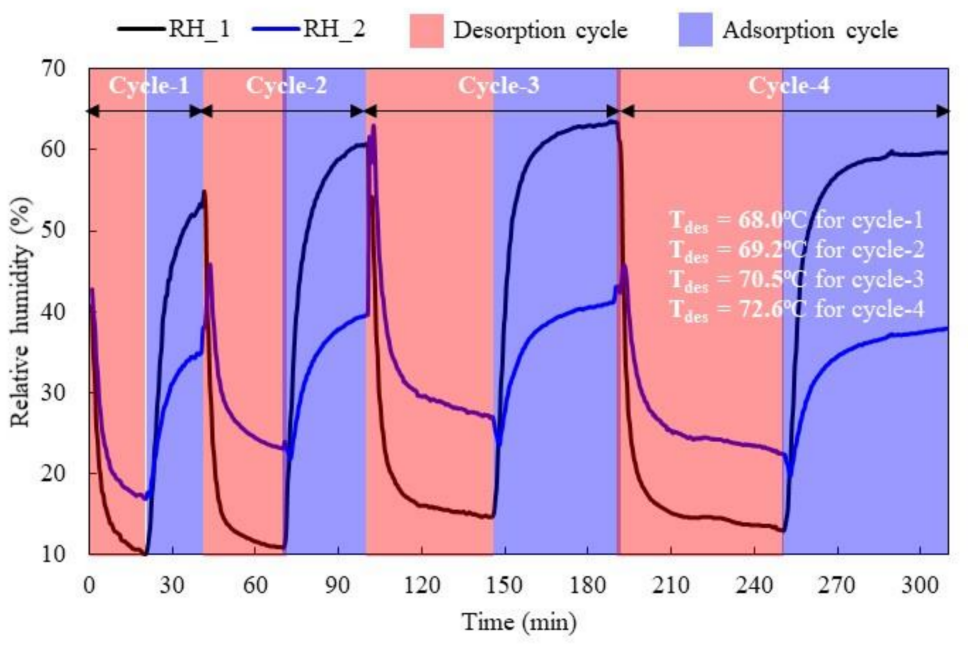

Figure 11. Experimental desorption/regeneration and adsorption/dehumidification cycle profiles of relative humidity for the DAC system at different desorption temperature $\left(T_{d e s}\right)$.

Figure 12 shows experimental desorption and adsorption cycle profiles of humidity ratio for the developed DAC system. The adsorption cycle-4 represents maximum adsorption potential due to higher desorption temperature. Figure 13 shows desorption and adsorption potential $(\Delta X)$ in different experimental cycles. In the desorption process, the amount of water vapours desorbed increases rapidly, and then reduces when saturation pressure of the process air and desiccant material surface approach equilibrium. Consequently, when the adsorption process starts, the amount of water vapours adsorbed is quite high, 
but gradually decreases and becomes steady due to saturation condition of the desiccant material. In Figure 13, the 60 min adsorption cycle-4 represents the maximum adsorption potential of $4.8 \mathrm{~g} / \mathrm{kg}$-DA via desiccant unit at desorption temperature of $72.6^{\circ} \mathrm{C}$, thereby showing the significance of switching time for the system and desorption temperature, which are the most important parameters for the feasibility of the DAC system [19]. Moreover, Aleem et al. [53] investigated the performance of laboratory scale silica gel-based DAC system thermodynamically. According to the results, maximum adsorption potential and coefficient of performance was observed at higher desorption temperature of $70{ }^{\circ} \mathrm{C}$ and $60 \mathrm{~min}: 60 \mathrm{~min}$ cycle time. In this regard, the adsorption cycle- 4 has been explored for performance evaluation of the developed system.

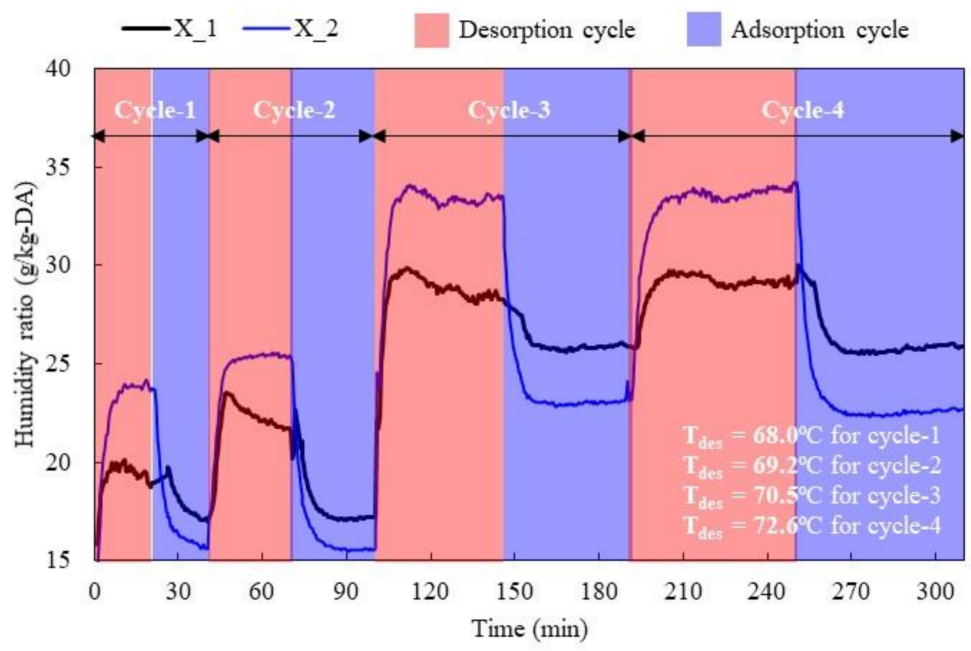

Figure 12. Experimental desorption/regeneration and adsorption/dehumidification cycle profiles of humidity ratio for the DAC system at different desorption temperature $\left(T_{\text {des }}\right)$.

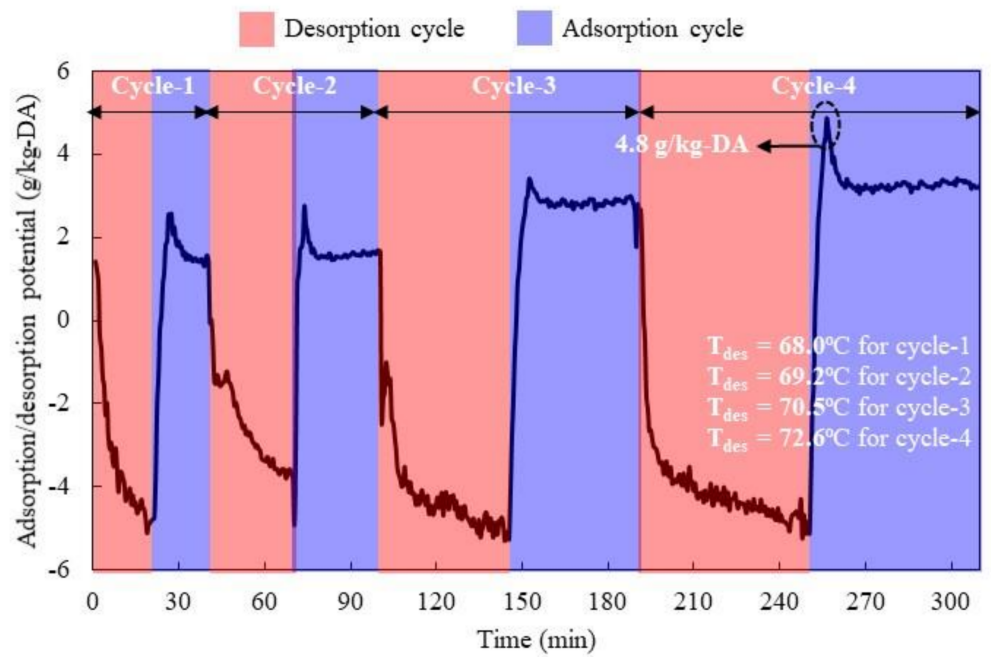

Figure 13. Adsorption and desorption potential in various experimental adsorption and desorption cycles of the DAC system at different desorption temperatures $\left(T_{d e s}\right)$.

The performance of the developed desiccant unit regarding energy consumption was explored from viewpoints of latent heat $\left(Q_{L}\right)$, sensible heat $\left(Q_{S}\right)$, total heat $(Q T)$ consumed by the system, and latent heat ratio (LHR) as shown in Figure 14. The $Q_{L}$ consumed by the system during the adsorption process varied between $0.02 \mathrm{kWh}$ and $0.64 \mathrm{kWh}$. The $Q_{S}$ consumed by the system during desorption process varied between $0.20 \mathrm{~kW}$ and $1.16 \mathrm{~kW}$. The $Q_{S}$ was higher due to heat provided for desorption of water vapours from the desiccant material to regenerate it. The energy consumed to reach the high desorption temperature 
of $72.6^{\circ} \mathrm{C}$ directly influenced the total energy consumed by the system. In this regard, the $Q_{T}$ consumed by the system varied between $0.15 \mathrm{~kW}$ and $1.80 \mathrm{~kW}$ during both adsorption and desorption processes. However, the $Q_{T}$ consumption could be reduced by maintaining a lower desorption temperature while, according to the experimental results, a higher desorption temperature was necessary for maximum adsorption potential. The electricity consumed by the fan was found to be $6.38 \mathrm{~W}$. The LHR by the developed system varied between 0.02 and 0.49 . The proposed air-conditioning (AC) systems are energy-efficient as compared with conventional refrigeration-based AC systems as discussed in Section 1.
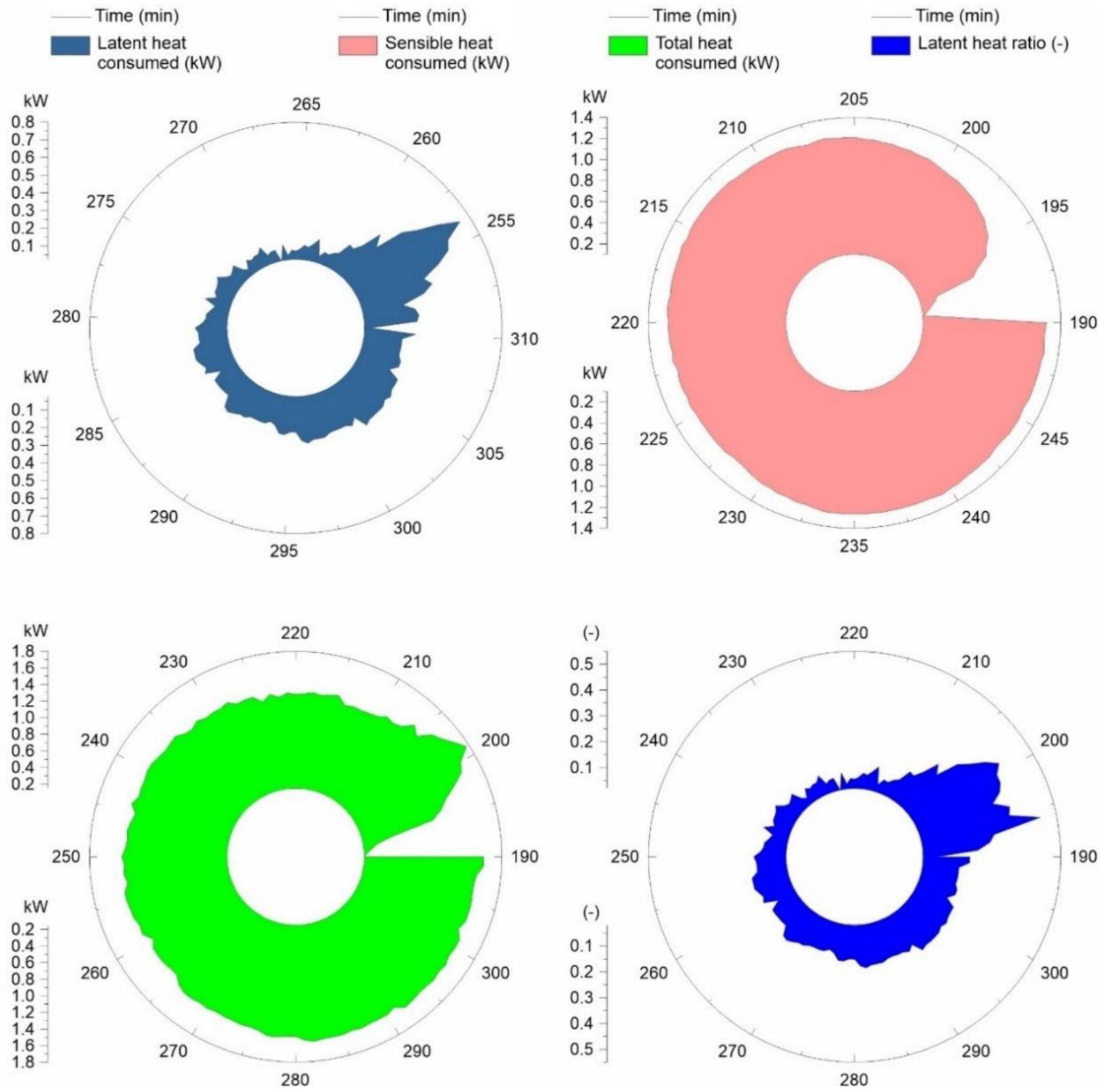

Figure 14. Latent heat $\left(Q_{L}\right)$, sensible heat $\left(Q_{S}\right)$, and total heat $\left(Q_{T}\right)$ consumed by the experimental system, and latent heat ratio (LHR) achieved by the system during desorption and adsorption cycle-4.

Figure 15 shows temperature and relative humidity profiles for the adsorption cycle-4 using S-DAC, and M-DAC system. The temperature and relative humidity of the S-DAC system ranges between $39{ }^{\circ} \mathrm{C}$ and $48{ }^{\circ} \mathrm{C}$, and $35 \%$ and $66 \%$, respectively. Therefore, the S-DAC system was unable to achieve the appropriate temperature and relative humidity conditions for storage of the agricultural products. Similarly, the temperature and relative humidity of the M-DAC system ranges from $17^{\circ} \mathrm{C}$ to $25^{\circ} \mathrm{C}$, and $76 \%$ to $98 \%$, respectively, and could thereby be a potential option for the storage of agricultural products. The tem- 
perature and relative humidity profiles of the S-DAC, and M-DAC system for adsorption cycle-1, cycle-2, and cycle- 3 is available in Appendix A: Figures A1-A3, respectively.
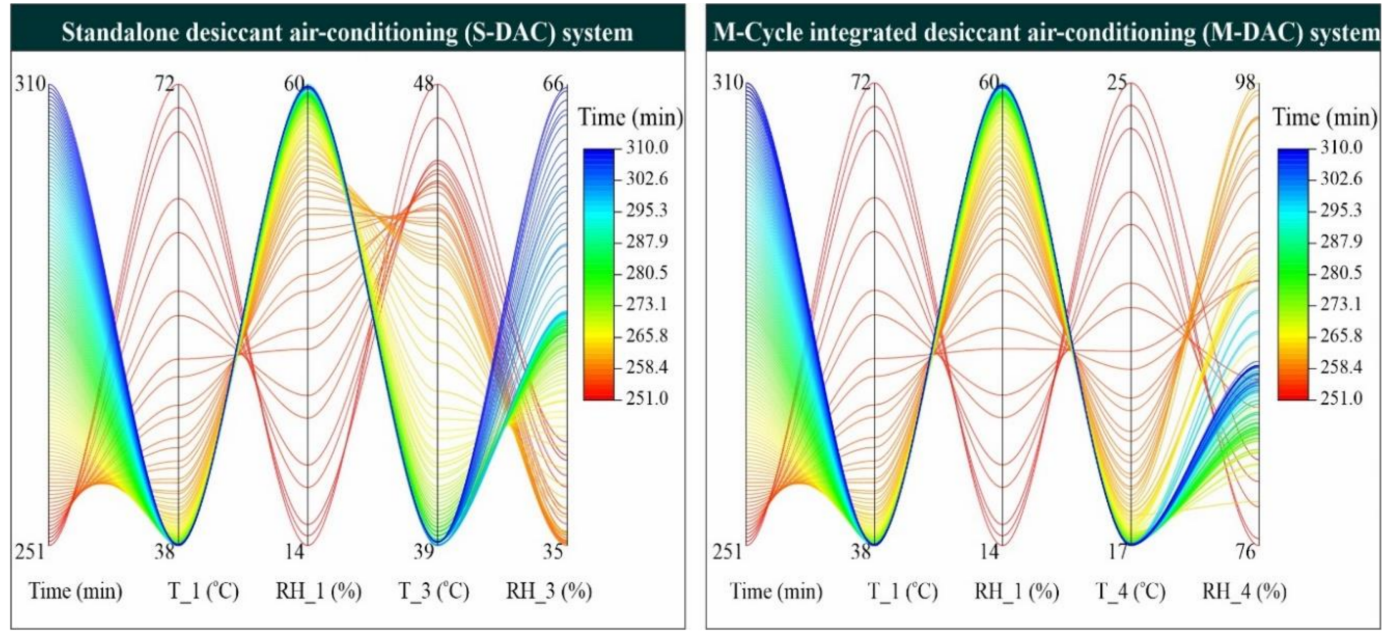

Figure 15. Profiles of temperature and relative humidity by the proposed S-DAC, and M-DAC system for adsorption cycle-4.

Figure 16 shows the cooling potential $\left(Q_{p}\right)$ of the S-DAC, and M-DAC systems for adsorption cycle-4. The $Q_{p}$ of the S-DAC, and M-DAC systems varied between $3.30 \mathrm{~kJ} / \mathrm{kg}$ and $17.50 \mathrm{~kJ} / \mathrm{kg}$, and $29.40 \mathrm{~kJ} / \mathrm{kg}$ to $41.80 \mathrm{~kJ} / \mathrm{kg}$, respectively. Figure 17 shows COP of the S-DAC and M-DAC systems for adsorption cycle-4. The COP for S-DAC and M-DAC systems varied between 0.058 and 0.368 , and 0.513 and 0.868 , respectively. Figure 18 shows psychrometric representation for performance of the proposed DAC systems. In Figure 18, the S-DAC system could not achieve appropriate temperature and relative humidity conditions for the storage of agricultural products. In contrast, the M-DAC system has achieved appropriate temperature and relative humidity conditions for the storage of agricultural products. Therefore, the M-DAC system could be utilized for the potential application of agricultural products storage.

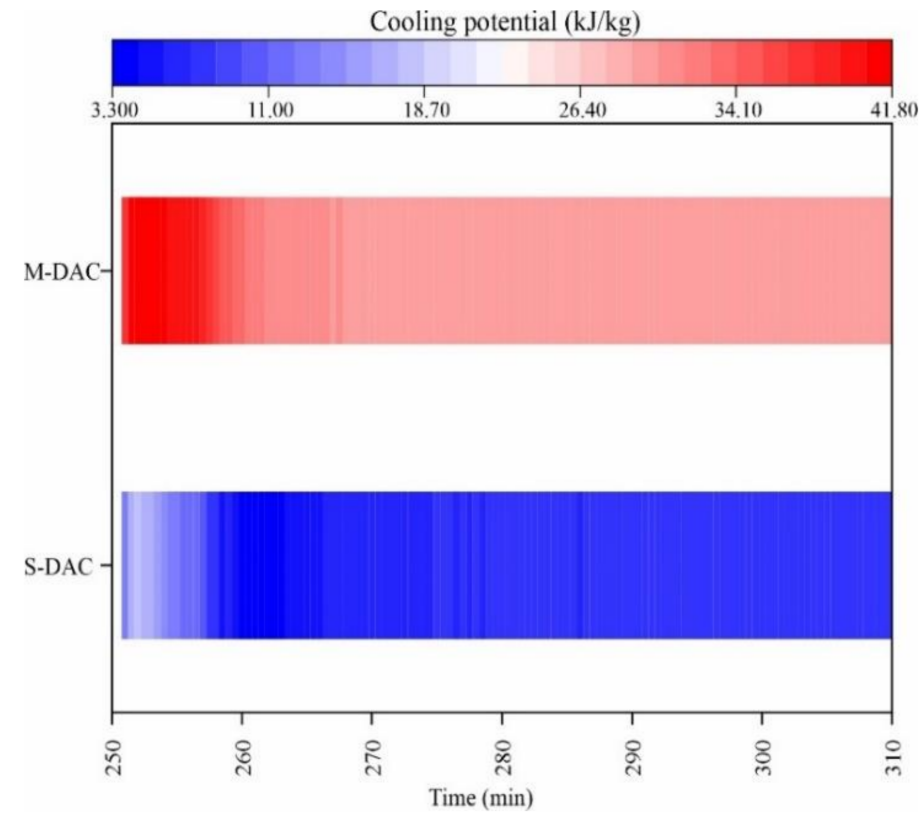

Figure 16. Profiles of cooling potential $\left(Q_{p}\right)$ by the proposed S-DAC, and M-DAC systems for adsorption cycle-4. 


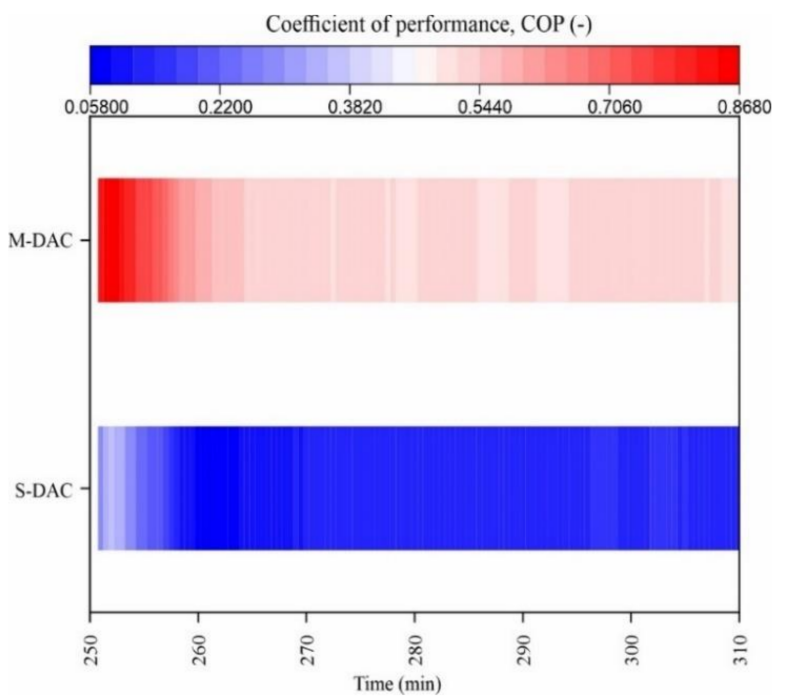

Figure 17. Profiles of COP by the proposed S-DAC, and M-DAC systems for adsorption cycle-4.

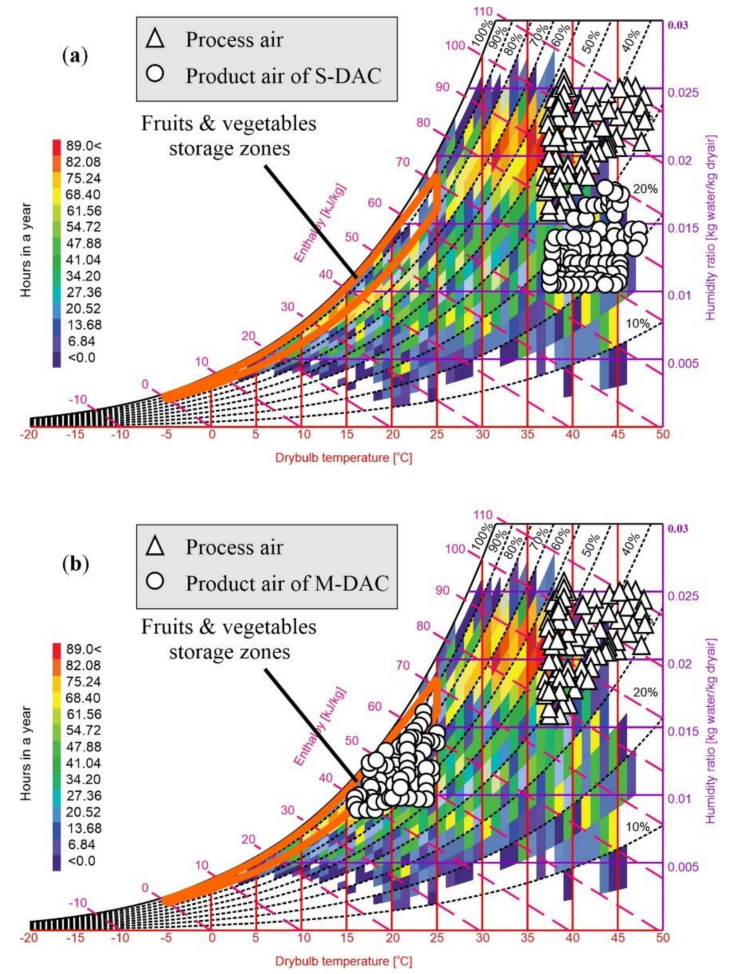

Figure 18. Psychrometric representation of process air and product air by the proposed (a) S-DAC, and (b) M-DAC systems.

The fruits and vegetables respire as living organism by emitting carbon dioxide to surrounding environment, thereby causing respiratory heat generation $\left(Q_{\text {res }}\right)$. The $Q_{\text {res }}$ vary with temperature and type of the product. Figure 19 shows the effect of temperature on the $Q_{\text {res }}$ by some fruits and vegetables. The $Q_{\text {res }}$ increases with temperature, hence during storage respiration process should be kept as low as possible to avoid heat generation from the product. In addition, heat is removed from the product due to the $Q_{\text {rate }}$ between product and ambient or surrounding air i.e., the difference between surface temperature of product and surrounding air temperature $(\Delta T)$, and velocity of air.

Figure 20 shows the effect of the $\Delta T$ and air velocity on the $Q_{\text {rate }}$ by some selected fruits (apple, grape, orange, pear, and tomato). The $Q_{\text {rate }}$ by fruits increases with increase in air velocity and $\Delta T$. In case of apple the $Q_{\text {rate }}$ at $0.91 \mathrm{~m} / \mathrm{s}$, with $\Delta T$ of $5^{\circ} \mathrm{C}$ was $1.58 \mathrm{~W}$, but at 
same velocity with $\Delta \mathrm{T}$ of $10^{\circ} \mathrm{C}, 15^{\circ} \mathrm{C}$, and $20^{\circ} \mathrm{C}$, the $Q_{\text {rate }}$ was $3.16 \mathrm{~W}, 4.75 \mathrm{~W}$, and $6.33 \mathrm{~W}$, respectively. A similarly increasing trend of the $Q_{\text {rate }}$ at different air velocity and $\Delta T$ was observed by other selected fruits. Likewise, Figure 21 shows the effect of $\Delta T$ on the $Q_{\text {rate }}$ by some selected vegetables (cabbage, carrot, onion, and potato). The $Q_{\text {rate }}$ by vegetables increases with $\Delta T$. In case of cabbage, $Q_{\text {rate }}$ at $0.431 \mathrm{~m} / \mathrm{s}$ with $\Delta T$ of $5^{\circ} \mathrm{C}$ was $0.116 \mathrm{~W}$, but at same velocity with $\Delta T$ of $10^{\circ} \mathrm{C}, 15^{\circ} \mathrm{C}$, and $20^{\circ} \mathrm{C}$ the $Q_{\text {rate }}$ was $0.22 \mathrm{~W}, 0.33 \mathrm{~W}$, and $0.45 \mathrm{~W}$, respectively. A comparable trend was observed for other selected vegetables. Furthermore, higher air velocities and higher relative humidity of surrounding air caused wilting of fruits and vegetables. The appropriate air velocity is varied with size of storage house. The recommended air velocity is about $0.003 \mathrm{~m} / \mathrm{s}$ for storage house having area of $10 \mathrm{~m}^{2}$, and relative humidity of about $90 \%$ to $95 \%$ [50].
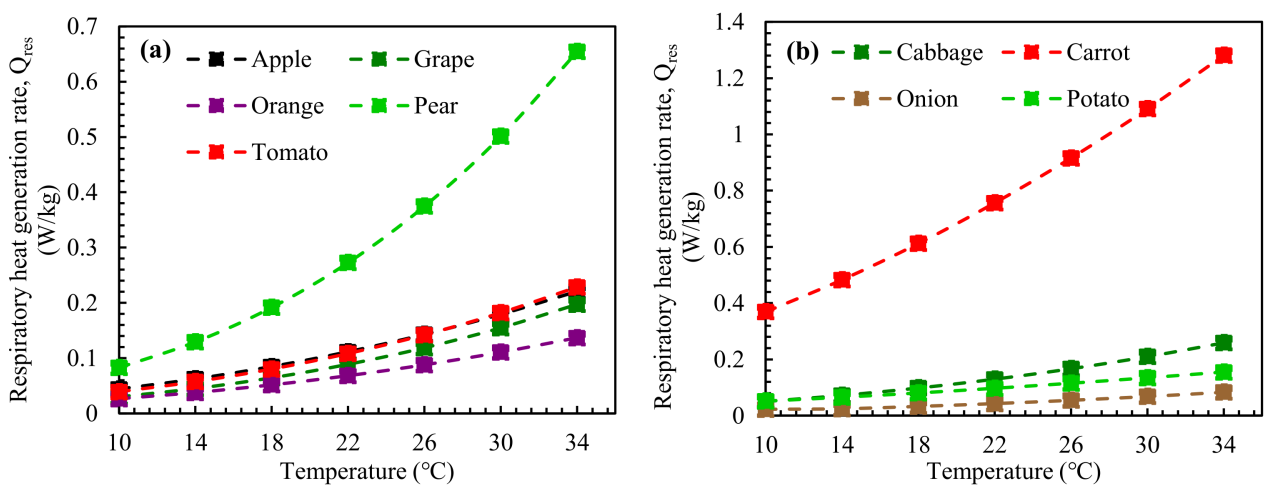

Figure 19. Effect of temperature on respiration rate $\left(Q_{\text {res }}\right)$ by some $(\mathbf{a})$ fruits, and (b) vegetables.
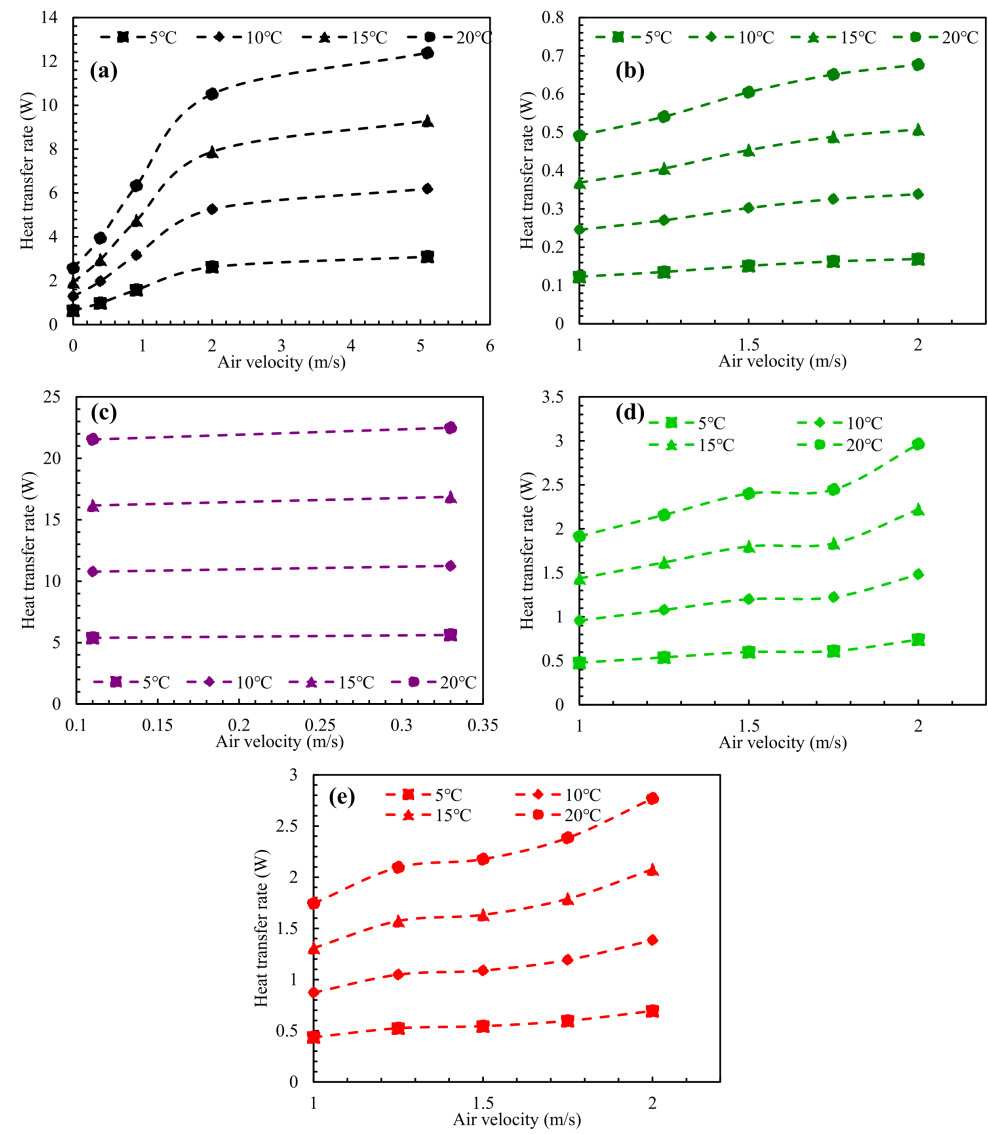

Figure 20. Effect of temperature gradient $(\Delta T)$ and air velocity on the heat transfer rate $\left(Q_{\text {rate }}\right)$ by (a) apple, (b) grape, (c) orange, (d) pear, and (e) tomato. 

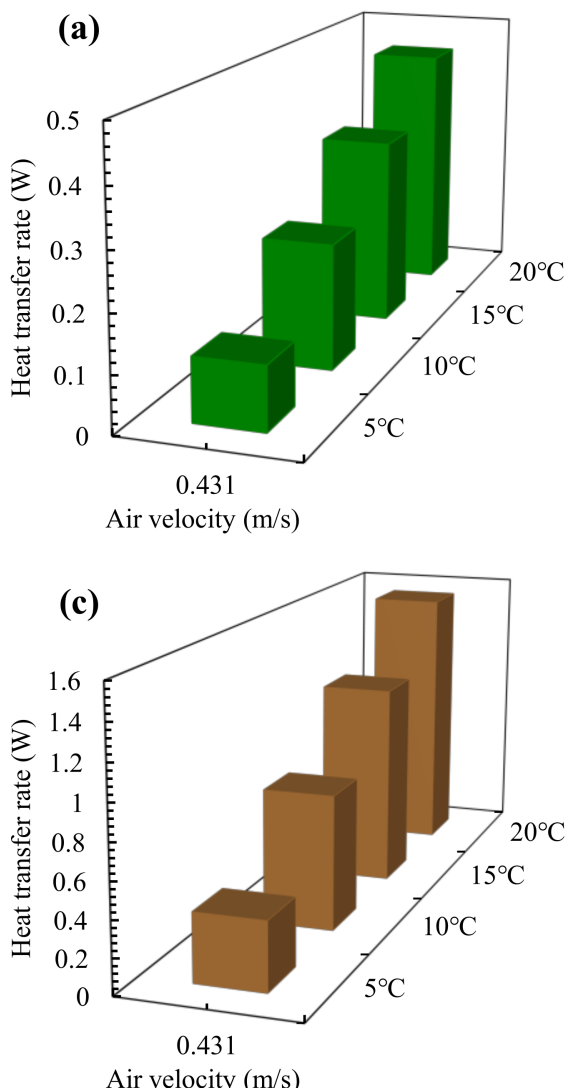
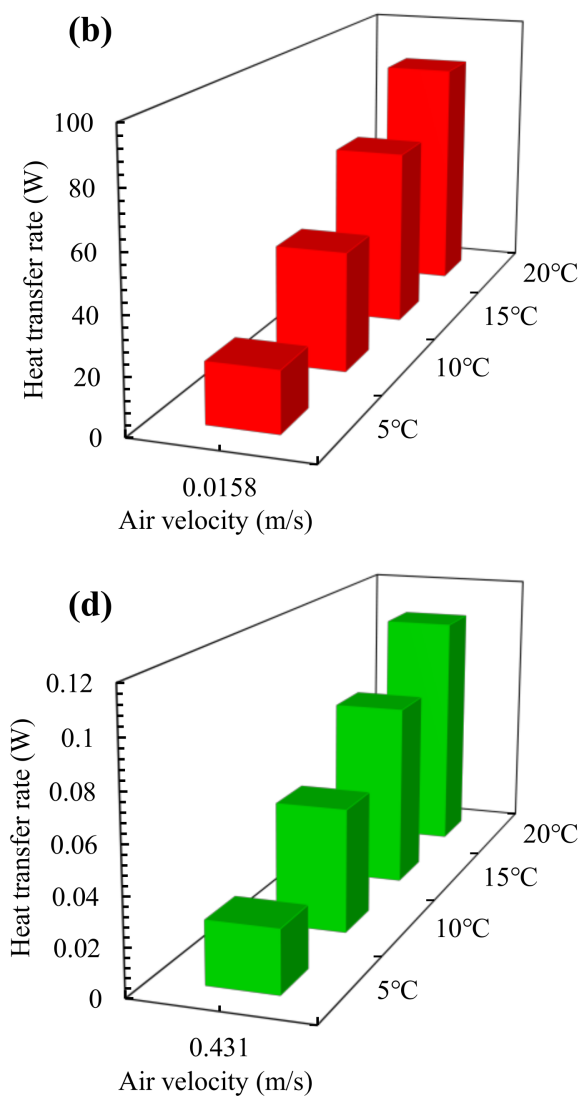

Figure 21. Effect of temperature gradient $(\Delta T)$ on the heat transfer rate $\left(Q_{\text {rate }}\right)$ by (a) cabbage, (b) carrot, (c) onion, and (d) potato.

\section{Conclusions}

The present study aims to evaluate the Maisotsenko cycle evaporative cooling assisted solid desiccant air-conditioning (M-DAC) system for agricultural storage application. The agricultural products required appropriate temperature and relative humidity conditions for their efficient storage to avoid post-harvest losses. In this regard, the air-conditioning (AC) system is principally required to optimize the temperature and relative humidity conditions, which could potentially reduce post-harvest losses. Therefore, in this study, a lab-scale solid silica gel-based desiccant AC (DAC) system was developed. The performance of the developed system was investigated thermodynamically, using various adsorption/dehumidification and desorption/regeneration cycles. The system possesses better performance in terms of adsorption potential $\left(Q_{p}\right)$ i.e., $4.88 \mathrm{~g} / \mathrm{kg}$-DA at higher desorption temperature i.e., $72.6^{\circ} \mathrm{C}$ and comparatively long cycle time i.e., $60 \mathrm{~min}: 60 \mathrm{~min}$. Furthermore, performance of the developed system regarding energy consumption was investigated from viewpoints of latent heat $\left(Q_{L}\right)$, sensible heat $\left(Q_{S}\right)$, and total heat $\left(Q_{T}\right)$ as well as latent heat ratio (LHR). The maximum consumption of $Q_{L}, Q_{S}$, and $Q_{T}$, by the system was found to be $0.64 \mathrm{~kW}, 1.16 \mathrm{~kW}$, and $1.80 \mathrm{~kW}$, respectively by achieving the maximum LHR of 0.49 .

Furthermore, the study proposed two kinds of AC options involving standalone DAC (S-DAC), and M-DAC systems to investigate applicability of these systems for agricultural storage application. The proposed systems were compared thermodynamically from perspectives of temperature as well as relative humidity ranges, cooling potential $\left(Q_{p}\right)$, and coefficient of performance (COP). The S-DAC system showed temperature and relative humidity ranging from $39^{\circ} \mathrm{C}$ to $48{ }^{\circ} \mathrm{C}$, and $35 \%$ to $66 \%$, respectively, with $Q_{p}$ and COP of $17.55 \mathrm{~kJ} / \mathrm{kg}$, and 0.37 , respectively, which were inappropriate conditions for agricultural storage. Conversely, the M-DAC system showed temperature and relative humidity ranging from $17^{\circ} \mathrm{C}$ to $25^{\circ} \mathrm{C}$, and $76 \%$ to $98 \%$, respectively, with $Q_{p}$ and COP of $41.80 \mathrm{~kJ} / \mathrm{kg}$, and 
0.87, respectively which lies somehow between appropriate conditions for the agricultural products storage application. Additionally, the study investigated respiratory heat generation rate $\left(Q_{\text {res }}\right)$, and heat transfer rate $\left(Q_{\text {rate }}\right)$ by some fruits and vegetables at different temperature gradient $(\Delta T)$ and air velocity. The $Q_{\text {res }}$ and $Q_{\text {rate }}$ by the fruits and vegetables were increased with temperature, and $\Delta T$ as well as air velocity, respectively. These heat loads reduced shelf life and quality of agricultural products. Therefore, the M-DAC system could be a potential AC option for agricultural storage application.

Author Contributions: Conceptualization, G.H.; methodology, G.H.; software, G.H. and M.A.; validation, M.S., U.S. and M.F.; formal analysis, G.H. and M.A.; investigation, G.H., M.A., M.S. and R.R.S.; resources, M.S.; data curation, G.H., M.A., U.S., R.R.S., M.U.K. and M.B.; writing-original draft preparation, G.H.; writing—review and editing, M.A., M.S., S.M.I., R.R.S., M.F., M.U.K. and M.B.; visualization, M.A., S.M.I., R.R.S., M.F. and M.U.K.; supervision, M.S.; project administration, M.S.; funding acquisition, S.M.I. and R.R.S. All authors have read and agreed to the published version of the manuscript.

Funding: This work was supported by Researchers Supporting Project number (RSP-2021/100), King Saud University, Riyadh, Saudi Arabia.

Institutional Review Board Statement: Not applicable.

Informed Consent Statement: Not applicable.

Data Availability Statement: The data is contained within the article.

Acknowledgments: This work was supported by Researchers Supporting Project number (RSP2021/100), King Saud University, Riyadh, Saudi Arabia. All this work is part of the Ph.D. research of Ghulam Hussain (1st author). This research work was carried in the Department of Agricultural Engineering, Bahauddin Zakariya University, Multan, Pakistan. The authors acknowledge the financial support by the Open Access Publication Fund of the Leibniz Association, Germany.

Conflicts of Interest: The authors declare no conflict of interest.

\section{Nomenclature}

$\begin{array}{ll}\text { AC } & \text { air-conditioning } \\ A_{S} & \text { surface area of product }\left(\mathrm{m}^{2}\right) \\ \text { COP } & \text { coefficient of performance } \\ C_{p} & \text { specific heat capacity of air }(\mathrm{kJ} / \mathrm{kg} \mathrm{K}) \\ \text { DAC } & \text { desiccant air-conditioning } \\ d P & \text { pressure drop }(\mathrm{kPa}) \\ \text { EC } & \text { evaporative cooling } \\ f & \text { respiratory coefficient }(-) \\ g & \text { respiratory coefficient }(-) \\ h & \text { air enthalpy }(\mathrm{kJ} / \mathrm{kg}) \\ h_{s} & \text { surface heat transfer coefficient }\left(\mathrm{W} / \mathrm{m}^{2}{ }^{\circ} \mathrm{C}\right) \\ \text { LHR } & \text { latent heat ratio }(\mathrm{LHR}) \\ \mathrm{M}-\mathrm{DAC} & \text { Maisotsenko-Cycle integrated desiccant air-conditioning } \\ \mathrm{MEC} & \text { Maisotsenko-Cycle evaporative cooling } \\ \dot{m}_{a} & \text { mass flow rate }(\mathrm{kg} / \mathrm{s}) \\ N_{1}-N_{n} & \text { independent variables } \\ \mathrm{p} & \text { cooling potential }(\mathrm{kJ} \mathrm{kg}) \\ Q_{T} & \text { total heat consumption }(\mathrm{kW}) \\ Q_{L} & \text { latent heat consumption }(\mathrm{kW}) \\ Q_{S} & \text { sensible heat consumption }(\mathrm{kW}) \\ Q_{F} & \text { electricity consumption by fan }(\mathrm{kW}) \\ Q_{p} & \text { cooling potential }(\mathrm{kJ} / \mathrm{kg}) \\ Q_{r e s} & \text { respiratory heat generation rate }(\mathrm{W} / \mathrm{kg}) \\ Q_{\text {rate }} & \text { heat transfer rate }(\mathrm{W}) \\ \mathrm{S}-\mathrm{D} \text { AC } & \text { standalone desiccant air-conditioning } \\ & \end{array}$




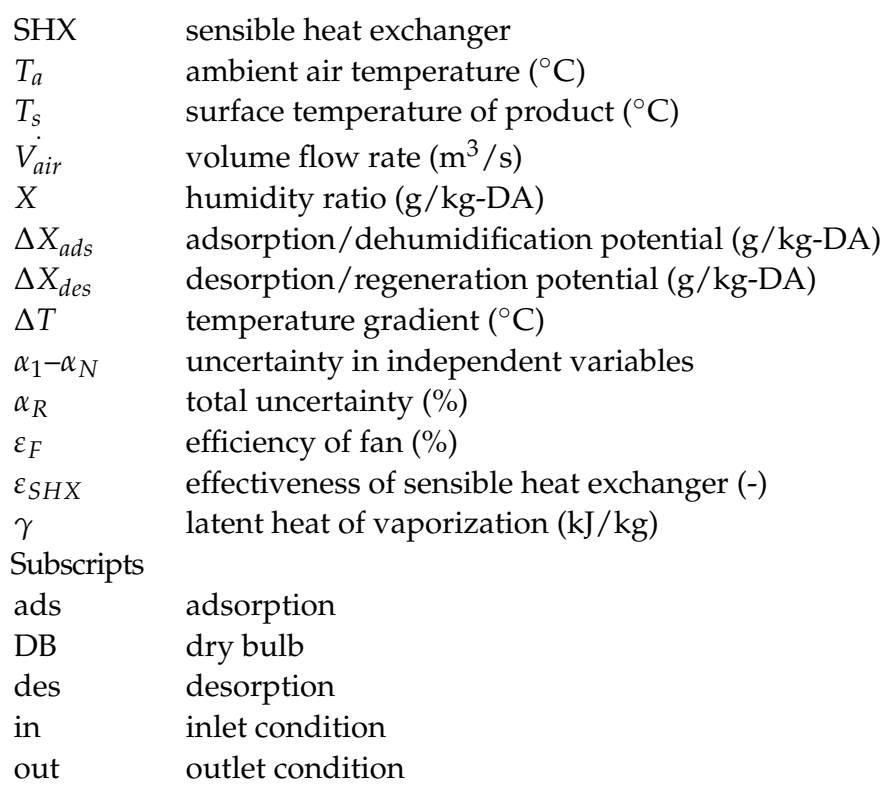

\section{Appendix A}
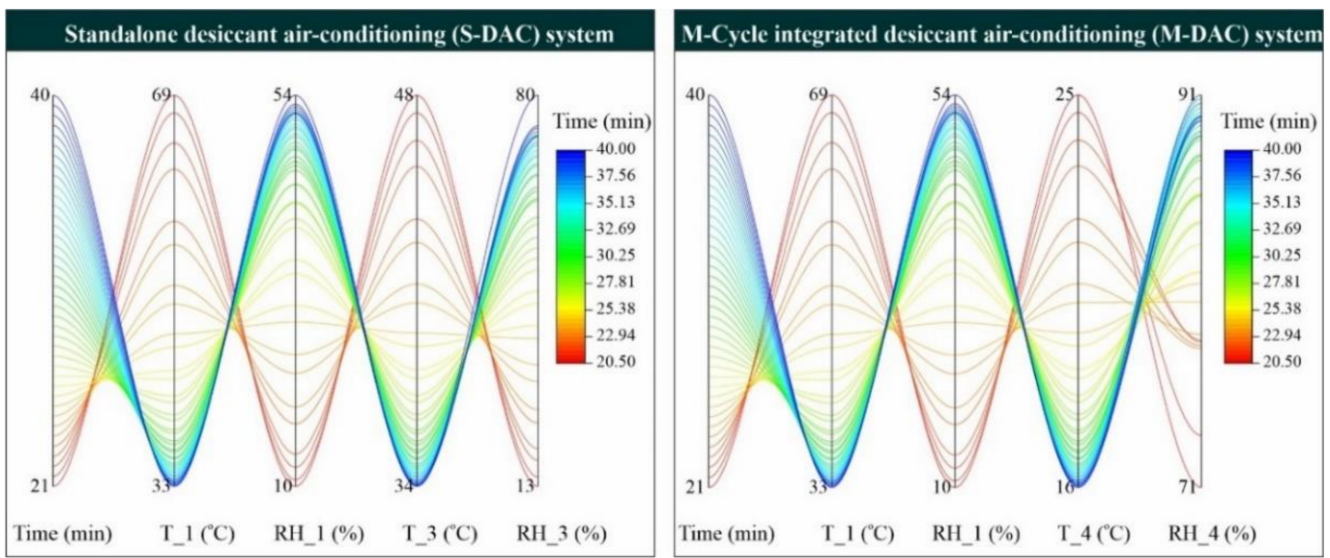

Figure A1. Profiles of temperature and relative humidity of the S-DAC, and M-DAC system for adsorption/dehumidification cycle-1.
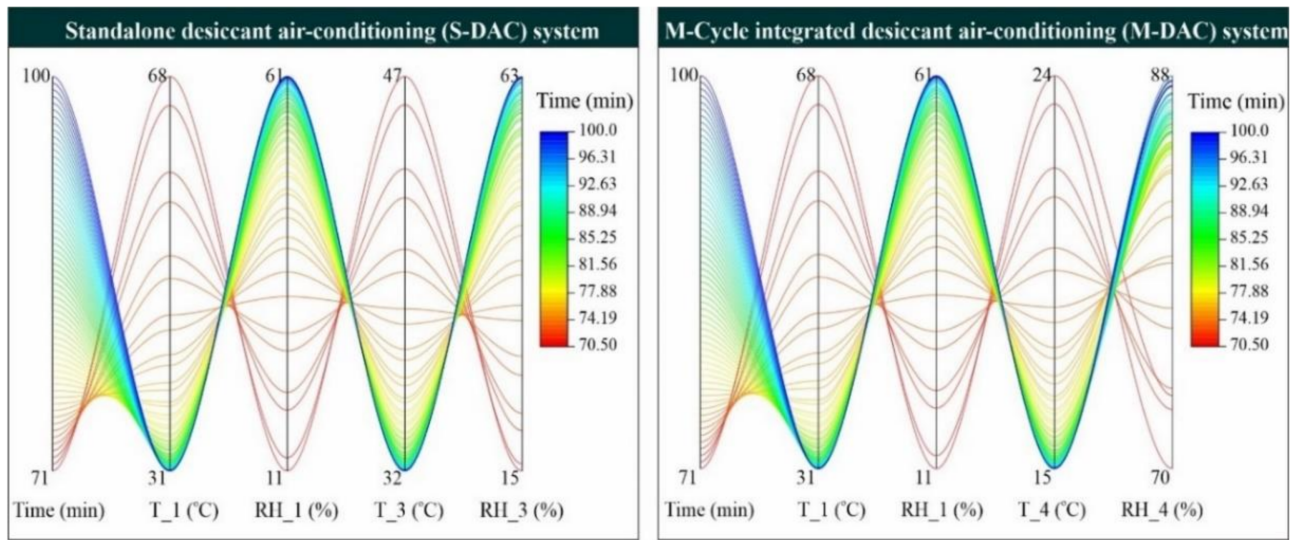

Figure A2. Profiles of temperature and relative humidity of the S-DAC, and M-DAC system for adsorption/dehumidification cycle-2. 

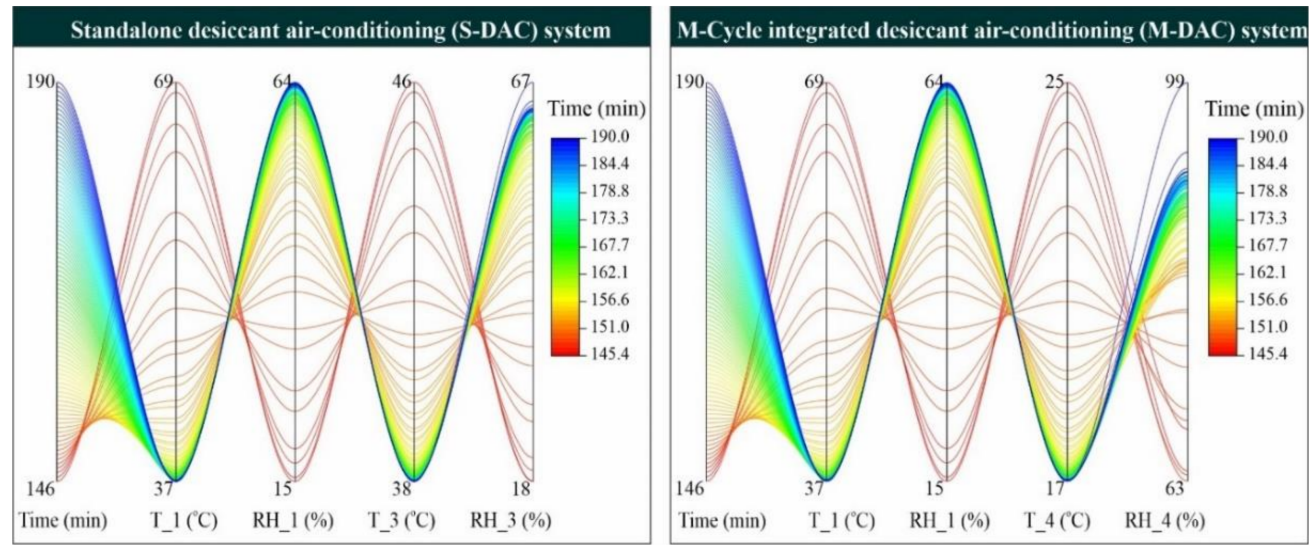

Figure A3. Profiles of temperature and relative humidity of the S-DAC, and M-DAC system for adsorption/dehumidification cycle-3.

\section{References}

1. Noya, I.; González-García, S.; Bacenetti, J.; Fiala, M.; Moreira, M.T. Environmental Impacts of the Cultivation-Phase Associated with Agricultural Crops for Feed Production. J. Clean. Prod. 2018, 172, 3721-3733. [CrossRef]

2. Abbas, M.; Maqsood, W.; Ijaz, M.; Hashim, M.Y. Post-Harvest Losses in Fruits and Vegetables in Pakistan. Available online: https: / / agrihunt.com/articles/pak-agri-outlook/post-harvest-losses-in-fruits-and-vegetables-in-pakistan/ (accessed on 9 June 2021).

3. Ishaq, M.; Sultan, M.; Aleem, M.; Bilal, M.; Ullah, H.S.; Mahmood, M.H.; Miyazaki, T. Desiccant Dehumidification System for Storage of Fruits and Vegetables. In Energy-Efficient Systems for Agricultural Applications; Sultan, M.M.T., Ed.; Springer: Cham, Switzerland, 2022; pp. 65-83. [CrossRef]

4. Ishaq, M.; Aleem, M.; Ashraf, H.; Hafiz, S.U.; Sultan, M. Study on Desiccant Dehumidification System Using Experiments and Steady-State Model. In Proceedings of the International Exchange and Innovation Conference on Engineering \& Sciences (IEICES), Fukoka, Japan, 22-23 October 2020; Volume 6, pp. 92-97.

5. FAO; CIHEAM. Mediterra 2016: Zero Waste in the Mediterranean. In Natural Resources, Food and Knowledge; International Centre of Advanced Mediterranean Agronomic Studies (CHIEAM); FAO; Presses de Sciences PO: Paris, France, 2016.

6. Brasil, I.M.; Siddiqui, M.W. Chapter 1-Postharvest Quality of Fruits and Vegetables: An Overview; Siddiqui, M.W., Ed.; Academic Press: Amsterdam, The Netherlands, 2018; pp. 1-40.

7. Sultan, M.; El-Sharkawy, I.I.; Miyazaki, T.; Saha, B.B.; Koyama, S. An Overview of Solid Desiccant Dehumidification and Air Conditioning Systems. Renew. Sustain. Energy Rev. 2015, 46, 16-29. [CrossRef]

8. Mahmood, M.H.; Sultan, M.; Miyazaki, T. Significance of Temperature and Humidity Control for Agricultural Products Storage: Overview of Conventional and Advanced Options. Int. J. Food Eng. 2019, 15, 20190063. [CrossRef]

9. Mahmood, M.H.; Sultan, M.; Miyazaki, T.; Koyama, S.; Maisotsenko, V.S. Overview of the Maisotsenko Cycle-A Way towards Dew Point Evaporative Cooling. Renew. Sustain. Energy Rev. 2016, 66, 537-555. [CrossRef]

10. Pandelidis, D.; Anisimov, S. Numerical Analysis of the Heat and Mass Transfer Processes in Selected M-Cycle Heat Exchangers for the Dew Point Evaporative Cooling. Energy Convers. Manag. 2015, 90, 62-83. [CrossRef]

11. Asfahan, H.M.; Sajjad, U.; Sultan, M.; Hussain, I.; Hamid, K.; Ali, M.; Wang, C.-C.; Shamshiri, R.R.; Khan, M.U. Artificial Intelligence for the Prediction of the Thermal Performance of Evaporative Cooling Systems. Energies 2021, 14, 3946. [CrossRef]

12. Pandelidis, D.; Anisimov, S.; Worek, W.M. Performance Study of the Maisotsenko Cycle Heat Exchangers in Different AirConditioning Applications. Int. J. Heat Mass Transf. 2015, 81, 207-221. [CrossRef]

13. Caliskan, H.; Hepbasli, A.; Dincer, I.; Maisotsenko, V. Thermodynamic Performance Assessment of a Novel Air Cooling Cycle: Maisotsenko Cycle. Int. J. Refrig. 2011, 34, 980-990. [CrossRef]

14. Zhan, C.; Duan, Z.; Zhao, X.; Smith, S.; Jin, H.; Riffat, S. Comparative Study of the Performance of the M-Cycle Counter-Flow and Cross-Flow Heat Exchangers for Indirect Evaporative Cooling-Paving the Path toward Sustainable Cooling of Buildings. Energy 2011, 36, 6790-6805. [CrossRef]

15. Chua, K.J.; Chou, S.K.; Yang, W.M.; Yan, J. Achieving Better Energy-Efficient Air Conditioning-A Review of Technologies and Strategies. Appl. Energy 2013, 104, 87-104. [CrossRef]

16. Lal Basediya, A.; Samuel, D.V.K.; Beera, V. Evaporative Cooling System for Storage of Fruits and Vegetables-A Review. J. Food Sci. Technol. 2013, 50, 429-442. [CrossRef] [PubMed]

17. Sultan, M.; Miyazaki, T. Energy-Efficient Air-Conditioning Systems for Nonhuman Applications. In Refrigeration; Ekren, O., Ed.; InTech: London, UK, 2017; pp. 97-117.

18. Sultan, M.; Miyazaki, T.; Koyama, S.; Khan, Z.M. Performance Evaluation of Hydrophilic Organic Polymer Sorbents for Desiccant Air-Conditioning Applications. Adsorpt. Sci. Technol. 2018, 36, 311-326. [CrossRef] 
19. Kashif, M.; Sultan, M.; Khan, Z.M. Alternative Air-Conditioning Options for Developing Countries. Eur. J. Eng. Res. Sci. 2017, 2, 76. [CrossRef]

20. Sultan, M.; Miyazaki, T.; Koyama, S. Optimization of Adsorption Isotherm Types for Desiccant Air-Conditioning Applications. Renew. Energy 2018, 121, 441-450. [CrossRef]

21. Xue, B.; Tahara, K.; Nakashima, K.; Noda, A.; Oktariani, E.; Wijayanta, A.T.; Nakaso, K.; Fukai, J. Numerical Simulation for Steam Generation Process in a Novel Zeolite-Water Adsorption Heat Pump. J. Chem. Eng. Japan 2012, 45, 408-416. [CrossRef]

22. Xue, B.; Ye, S.; Zhang, L.; Wei, X.; Nakaso, K.; Fukai, J. High-Temperature Steam Generation from Low-Grade Waste Heat from an Adsorptive Heat Transformer with Composite Zeolite-13X/CaCl 2 . Energy Convers. Manag. 2019, 186, 93-102. [CrossRef]

23. Oktariani, E.; Tahara, K.; Nakashima, K.; Noda, A.; Xue, B.; Wijayanta, A.T.; Nakaso, K.; Fukai, J. Experimental Investigation on the Adsorption Process for Steam Generation Using a Zeolite-Water System. J. Chem. Eng. Japan 2012, 45, 355-362. [CrossRef]

24. Niu, X.; Xiao, F.; Ge, G. Performance Analysis of Liquid Desiccant Based Air-Conditioning System under Variable Fresh Air Ratios. Energy Build. 2010, 42, 2457-2464. [CrossRef]

25. Jia, C.X.; Dai, Y.J.; Wu, J.Y.; Wang, R.Z. Analysis on a Hybrid Desiccant Air-Conditioning System. Appl. Therm. Eng. 2006, 26, 2393-2400. [CrossRef]

26. Bassuoni, M.M. Experimental Performance Study of a Proposed Desiccant Based Air Conditioning System. J. Adv. Res. 2014, 5, 87-95. [CrossRef]

27. Qi, R.; Lu, L.; Huang, Y. Parameter Analysis and Optimization of the Energy and Economic Performance of Solar-Assisted Liquid Desiccant Cooling System under Different Climate Conditions. Energy Convers. Manag. 2015, 106, 1387-1395. [CrossRef]

28. Qi, R.; Lu, L. Energy Consumption and Optimization of Internally Cooled/Heated Liquid Desiccant Air-Conditioning System: A Case Study in Hong Kong. Energy 2014, 73, 801-808. [CrossRef]

29. Luo, Y.; Shao, S.; Xu, H.; Tian, C.; Yang, H. Experimental and Theoretical Research of a Fin-Tube Type Internally-Cooled Liquid Desiccant Dehumidifier. Appl. Energy 2014, 133, 127-134. [CrossRef]

30. Mahmood, M.H.; Sultan, M.; Miyazaki, T. Solid Desiccant Dehumidification-Based Air-Conditioning System for Agricultural Storage Application: Theory and Experiments. Proc. Inst. Mech. Eng. Part A J. Power Energy 2020, 234, 534-547. [CrossRef]

31. Mahmood, M.H.; Sultan, M.; Miyazaki, T. Experimental Evaluation of Desiccant Dehumidification and Air-Conditioning System for Energy-Efficient Storage of Dried Fruits. Build. Serv. Eng. Res. Technol. 2020, 41, 454-465. [CrossRef]

32. Hussain, G.; Sultan, M.; Aleem, M. Study on Solid Desiccant Dehumidification Cooling System for the Storage of Fruits and Vegetables. In Proceedings of the International Exchange and Innovation Conference on Engineering \& Sciences (IEICES), Fukoka, Japan, 21 October 2021; Volume 7, pp. 295-301.

33. Ashraf, H.; Sultan, M.; Shamshiri, R.R.; Abbas, F.; Farooq, M.; Sajjad, U.; Md-Tahir, H.; Mahmood, M.H.; Ahmad, F.; Taseer, Y.R.; et al. Dynamic Evaluation of Desiccant Dehumidification Evaporative Cooling Options for Greenhouse AirConditioning Application in Multan (Pakistan). Energies 2021, 14, 1097. [CrossRef]

34. Sultan, M.; Miyazaki, T.; Saha, B.B.; Koyama, S. Steady-State Investigation of Water Vapor Adsorption for Thermally Driven Adsorption Based Greenhouse Air-Conditioning System. Renew. Energy 2016, 86, 785-795. [CrossRef]

35. Niaz, H.; Sultan, M.; Khan, A.A.; Miyazaki, T.; Feng, Y.; Khan, Z.M.; Niaz, Y.; Mahmood, M.H.; Ali, I.; Imran, M.A. Study on Evaporative Cooling Assisted Desiccant Air Conditioning System for Livestock Application in Pakistan. Fresenius Environ. Bull. 2019, 28, 8623-8633.

36. Kashif, M.; Niaz, H.; Sultan, M.; Miyazaki, T.; Feng, Y.; Usman, M.; Shahzad, M.W.; Niaz, Y.; Waqas, M.M.; Ali, I. Study on Desiccant and Evaporative Cooling Systems for Livestock Thermal Comfort: Theory and Experiments. Energies 2020, 13, 2675. [CrossRef]

37. Aleem, M.; Sultan, M.; Mahmood, M.H.; Miyazaki, T. Desiccant Dehumidification Cooling System for Poultry Houses in Multan (Pakistan) BT-Energy-Efficient Systems for Agricultural Applications; Sultan, M., Miyazaki, T., Eds.; Springer International Publishing: Cham, Switzerland, 2022; pp. 19-42. [CrossRef]

38. Aleem, M.; Hussain, G.; Sultan, M.; Miyazaki, T. Lab-Scale Study of Desiccant Dehumidification System for Poultry Shed Air-Conditioning in Pakistan. In Proceedings of the International Exchange and Innovation Conference on Engineering \& Sciences (IEICES), Fukoka, Japan, 22-23 October 2020; Volume 6, pp. 85-91.

39. Aleem, M.; Sultan, M. Towards the Development of Energy-Efficient Poultry Air Conditioning System. Available online: https://www.researchgate.net/publication/354138144_Towards_the_development_of_energy-efficient_poultry_air_ conditioning_system (accessed on 9 June 2021).

40. Sultan, M.; Aleem, M.; Miyazaki, T. Energy-Efficient Humidity Pump System for Poultry Houses. In Synergy Development in Renewables Assisted Multi-Carrier Systems; Amidpour, M., Ebadollahi, M., Jabari, F., Kolahi, M.R., Ghaebi, H., Eds.; Springer: Cham, Switzerland, 2022. [CrossRef]

41. Xu, C.-J.; Guo, D.-P.; Yuan, J.; Yuan, G.-F.; Wang, Q.-M. Changes in Glucoraphanin Content and Quinone Reductase Activity in Broccoli (Brassica oleracea var. italica) Florets during Cooling and Controlled Atmosphere Storage. Postharvest Biol. Technol. 2006, 42, 176-184. [CrossRef]

42. Nampan, K.; Techavuthiporn, C.; Kanlayanarat, S. Hydrocooling Improves Quality and Storage Life of "Rong-Rein" Rambutan (Nephellium lappaceum L.) Fruit. Acta Hortic. 2006, 712, 763-769. [CrossRef]

43. Nunes, M.C.N.; Émond, J.P.; Brecht, J.K. Predicting Shelf Life and Quality of Raspberries under Different Storage Temperatures. Acta Hortic. 2003, 628, 599-606. [CrossRef] 
44. Paull, R.E. Effect of Temperature and Relative Humidity on Fresh Commodity Quality. Postharvest Biol. Technol. 1999, 15, $263-277$. [CrossRef]

45. Nunes, M.C.D.N. Impact of Environmental Conditions on Fruit and Vegetable Quality. Stewart Postharvest Rev. 2008, 4, 1-14. [CrossRef]

46. ASHRAE. Handbook of Fundamentals; American Society of Heating, Refrigerating and Air-Conditioning Engineers, Inc.: Atlanta, GA, USA, 2017.

47. Arah, I.K.; Amaglo, H.; Kumah, E.K.; Ofori, H. Preharvest and Postharvest Factors Affecting the Quality and Shelf Life of Harvested Tomatoes: A Mini Review. Int. J. Agron. 2015, 2015. [CrossRef]

48. Mahajan, P.V.; Rodrigues, F.A.S.; Motel, A.; Leonhard, A. Development of a Moisture Absorber for Packaging of Fresh Mushrooms (Agaricus bisporous). Postharvest Biol. Technol. 2008, 48, 408-414. [CrossRef]

49. ASHRAE. Handbook of Heating, Ventilation, and Air-Conditioning Application; American Society of Heating, Refrigerating and Air-Conditioning Engineers, Inc.: Atlanta, GA, USA, 2019.

50. Gross, K.C.; Wang, C.Y.; Mikal, S. The Commercial Storage of Fruits, Vegetables, and Florist and Nursery Stocks, 66th ed.; Kenneth, C.G., Wang, C.Y., Mikal, S., Eds.; United States Department of Agriculture, Agricultural Research Service: Washington, DC, USA, 2016.

51. Sultan, M.; El-Sharkawy, I.I.; Miyazaki, T.; Saha, B.B.; Koyama, S.; Maruyama, T.; Maeda, S.; Nakamura, T. Water Vapor Sorption Kinetics of Polymer Based Sorbents: Theory and Experiments. Appl. Therm. Eng. 2016, 106, 192-202. [CrossRef]

52. Sultan, M.; El-Sharkawy, I.I.; Miyazaki, T.; Saha, B.B.; Koyama, S.; Maruyama, T.; Maeda, S.; Nakamura, T. Insights of Water Vapor Sorption onto Polymer Based Sorbents. Adsorption 2015, 21, 205-215. [CrossRef]

53. Aleem, M.; Hussain, G.; Sultan, M.; Miyazaki, T.; Mahmood, M.H.; Sabir, M.I.; Nasir, A.; Shabir, F.; Khan, Z.M. Experimental Investigation of Desiccant Dehumidification Cooling System for Climatic Conditions of Multan (Pakistan). Energies 2020, 13, 5530. [CrossRef]

54. Sultan, M.; Miyazaki, T.; Niaz, H.; Shabir, F.; Ashraf, S.; Khan, Z.M.; Mahmood, M.H.; Raza, H.M.U. Thermodynamic Assessment of Solar Chimney Based Air-Conditioning System for Agricultural and Livestock Applications. In Proceedings of the 4th International Conference on Energy, Environment and Sustainable Development 2016 (EESD-2016), Jamshoro, Pakistan, 1-3 November 2016; Volume 2016, pp. 1-9.

55. Islam, M.R.; Alan, S.W.L.; Chua, K.J. Studying the Heat and Mass Transfer Process of Liquid Desiccant for Dehumidification and Cooling. Appl. Energy 2018, 221, 334-347. [CrossRef]

56. Esen, H.; Inalli, M.; Esen, M. Technoeconomic Appraisal of a Ground Source Heat Pump System for a Heating Season in Eastern Turkey. Energy Convers. Manag. 2006, 47, 1281-1297. [CrossRef]

57. Holman, J.P. Experimental Methods for Engineers; McGraw-Hill: New York, NY, USA, 2012.

58. Hepbasli, A.; Akdemir, O. Energy and Exergy Analysis of a Ground Source (Geothermal) Heat Pump System. Energy Convers. Manag. 2004, 45, 737-753. [CrossRef]

59. Becker, B.R.; Fricke, B.A. Simulation of Moisture Loss and Heat Loads in Refrigerated Storage of Fruits and Vegetables. New Dev. Refrig. Food Saf. Qual. 1996, 6, 210-221.

60. ASHRAE, ASHRAE Handbook-Refrigeration; American Society of Heating, Refrigerating, and Air-Conditioning Engineers, Inc.: Atlanta, GA, USA, 2014.

61. Rafiee, S.; Keyhani, A.; Tabatabaeefar, A. Some Physical Properties of Apple Cv. 'Golab'. Available online: https://cigrjournal. org/index.php/Ejounral/article/view/1124/1167 (accessed on 9 June 2021).

62. Dincer, I. Development of New Effective Nusselt-Reynolds Correlations for Air-Cooling of Spherical and Cylindrical Products. Int. J. Heat Mass Transf. 1994, 37, 2781-2787. [CrossRef]

63. Zhang, Y.; Keller, M. Grape Berry Transpiration Is Determined by Vapor Pressure Deficit, Cuticular Conductance, and Berry Size. Am. J. Enol. Vitic. 2015, 66, 454-462. [CrossRef]

64. Topuz, A.; Topakci, M.; Canakci, M.; Akinci, I.; Ozdemir, F. Physical and Nutritional Properties of Four Orange Varieties. J. Food Eng. 2005, 66, 519-523. [CrossRef]

65. Bennett, A.H.; Soule, J.; Yost, G.E. Temperature Response of Florida Citrus to Forced-Air Precooling. ASHRAE J. $1966,4,48-54$.

66. Babic, L.; Matic-Kekic, S.; Dedovic, N.; Babic, M.; Pavkov, I. Surface Area and Volume Modeling of the Williams Pear (Pyrus communis). Int. J. Food Prop. 2012, 15, 880-890. [CrossRef]

67. Beuchat, L.R.; Farber, J.N.; Garrett, E.H.; Harris, L.J.; Parish, M.E.; Suslow, T.V.; Busta, F.F. Standardization of a Method to Determine the Efficacy of Sanitizers in Inactivating Human Pathogenic Microorganisms on Raw Fruits and Vegetables. Compr. Rev. Food Sci. Food Saf. 2003, 2, 174-178. [CrossRef]

68. Phungamngoen, C.; Rittisak, S. Surface Characteristics of Leafy Vegetables and Their Effects on Salmonella Attachment. E3S Web Conf. 2020, 141, 1-5. [CrossRef]

69. Parashar, V.; Trivedi, S.K.; Haleem, A. Heat Transfer Parameterization towards Enhancing Shelf Life of Vegetables in Low Cost Cold Chain with FACCC. Int. J. Innov. Technol. Explor. Eng. 2020, 9, 822-829. [CrossRef]

70. Jahanbakhshi, A.; Abbaspour-Gilandeh, Y.; Gundoshmian, T.M. Determination of Physical and Mechanical Properties of Carrot in Order to Reduce Waste during Harvesting and Post-Harvesting. Food Sci. Nutr. 2018, 6, 1898-1903. [CrossRef] [PubMed]

71. Chang, S.Y.; Toledo, R.T. Simultaneous Determination of Thermal Diffusivity and Heat Transfer Coefficient during Sterilization of Carrot Dices in a Packed Bed. J. Food Sci. 1990, 55, 199-205. [CrossRef] 
72. Kaveri, G.; Thirupathi, V. Studies on Geometrical and Physical Properties of $\mathrm{CO}_{4}$ Onion Bulb (Allium cepa Lvar. Aggregatum Don.). Int. J. Rec. Sci. Res. 2015, 6, 2897-2902.

73. Gamea, G.R.; Abd El-Maksoud, M.A.; Abd El-Gawad, A.M. Physical Characteristics and Chemical Properties of Potato Tubers Under Different Storage Systems. Misr J. Agric. Eng. 2009, 26, 385-408. [CrossRef] 